\title{
Reactor Testing and Qualification: Prioritized High-Level Criticality Testing Needs
}

S. Bragg-Sitton

J. Bess

J. Werner

G. Harms

S. Bailey

September 2011

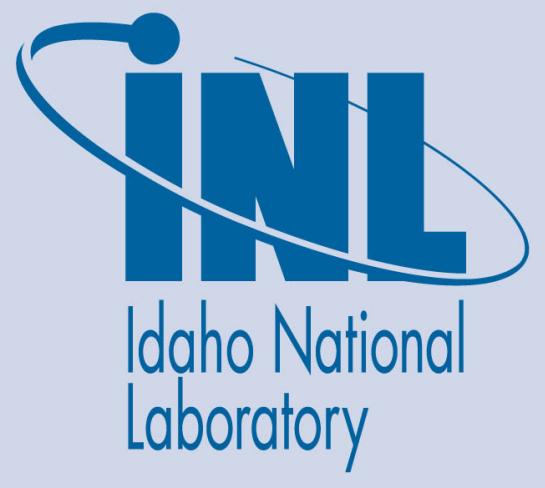

The INL is a U.S. Department of Energy National Laboratory operated by Battelle Energy Alliance 
INL/EXT-11-22725

\title{
Reactor Testing and Qualification: Prioritized High- Level Criticality Testing Needs
}

\author{
S. Bragg-Sitton \\ J. Bess \\ J. Werner \\ G. Harms \\ S. Bailey
}

September 2011

\section{Idaho National Laboratory \\ Idaho Falls, Idaho 83415}

http://www.inl.gov

\author{
Prepared for the \\ National Aeronautics and Space Administration \\ and for the \\ U.S. Department of Energy \\ Under DOE Idaho Operations Office \\ Contract DE-AC07-05ID14517
}


WBS Task Number: High Efficiency Space Power Systems (HESPS)-TBD,

Reactor Testing and Qualification

Task Name: $\quad$ Reactor Testing and Qualification

Performing Orgs: $\quad$ INL, SNL, LANL, S. Bailey

Task Objective: $\quad$ To identify the test needs and methods to achieve certainty of design while minimizing the amount of nuclear testing required during the design and development stages of this program.

Deliverable 1: $\quad$ Issue report on prioritized high-level criticality testing needs.

Report Authors: $\quad$ S. Bragg-Sitton, INL

J. Bess, INL

J. Werner, INL

G. Harms, SNL

S. Bailey

Task Description: An assessment describing the anticipated testing or analyses tasks necessary to provide the desired neutronic and material property data from a zero power critical test is required. The assessment should identify pertinent major testing or evaluation components of a reactor qualification campaign, and indicate the necessary validation and verification requirements of the identified tasks. The assessment will provide the basis for determining nuclear facility testing components versus non-nuclear facility testing components and the associated analytical activities of a qualification effort. The testing assessment would address issues associated data acquisition and validation, test acceptance criteria and general facility requirements.

- Develop testing and qualification strategy /approach

- Perform neutronic/kinetic analyses that demonstrate simplicity of reactor operation/response and quantify the affect of phenomena that cannot be addressed in a zero power critical test.

- Understand the capabilities of the DAF facility and assess impact on scope, schedule and ability to obtain the desired data.

\section{Deliverables:}

Discussions with NTS will begin to support and understand the facilities that would be available and the programmatic funding and schedule requirements of conducting desired critical tests. The report would describe the testing, analysis and tasks required to plan the initial set of critical tests. Further definition of zero power critical testing and definition of test data (values) needed for a cold critical.

- $\quad$ Issue report on prioritized high-level criticality testing needs (INL, June 2011).

- Issue report on test parameters and accuracies needed in the critical experiments for FPS (Bailey, June 2011).

- $\quad$ Issue letter report of reactor neutronic and kinetic calculations in an FSP model that demonstrate the effect of the uncertainty in the neutronic values to the design and stability of the reactor system (LANL, August 2011).

- $\quad$ Report on status of DAF facility's ability to meet DOE-NE criticals test requirements and safety authorization basis at DAF (September 2011). 


\section{Reactor Testing and Qualification: Prioritized High-level Criticality Testing Needs}

\section{Introduction}

Researchers at the Idaho National Laboratory (INL) were tasked with reviewing possible criticality testing needs to support development of the fission surface power system reactor design. Reactor physics testing can provide significant information to aid in development of technologies associated with small, fast spectrum reactors that could be applied for non-terrestrial power systems, leading to eventual system qualification. Several studies have been conducted in recent years to assess the data and analyses required to design and build a space fission power system with high confidence that the system will perform as designed [Marcille, 2004a, 2004b; Weaver, 2007; Parry et al., 2008].

This report will provide a summary of previous critical tests and physics measurements that are potentially applicable to the current reactor design (both those that have been benchmarked and those not yet benchmarked), summarize recent studies of potential nuclear testing needs for space reactor development and their applicability to the current baseline fission surface power (FSP) system design, and provide an overview of a suite of tests (separate effects, sub-critical or critical) that could fill in the information database to improve the accuracy of physics modeling efforts as the FSP design is refined. Some recommendations for tasks that could be completed in the near term are also included. Specific recommendations on critical test configurations will be reserved until after the sensitivity analyses being conducted by Los Alamos National Laboratory (LANL) are completed (due August 2011).

\section{I.A. Design Sensitivity Analysis}

The series of neutronic and kinetic calculations being conducted by LANL on the conceptual FSP model will demonstrate the effect of uncertainties in physics data (e.g. cross sections) on key parameters in the FSP conceptual design such as critical mass, control worth, reactivity under accident conditions, etc.

An earlier sensitivity analysis performed by Sandia National Laboratories (SNL) (work documented in a draft report by Harms and Barber, 2009) considered the sensitivity of an earlier version of the FSP reactor model [Poston 2008] to various parameters. This analysis considered perturbations to the ${ }^{235} \mathrm{U}$ atom density in the fuel, beryllium atom density in the radial reflector, oxygen atom density in the fuel, and beryllium oxide density in the fuel pin axial reflector. Material density is relatively easy to change in the reactor models, and can be used as an initial "gauge" of the sensitivity of a particular model to changes in specific materials or components. Model sensitivity to a given parameter or material is defined as the relative change in the effective multiplication factor $\left(\mathrm{k}_{\mathrm{eff}}\right)$ produced by a small change in that parameter. Perturbation of material density can indicate that a particular model is sensitive to either a particular material mass or total material cross section. The SNL analysis indicated that an FSP-class reactor would be most sensitive to changes in the ${ }^{235} \mathrm{U}$ atom density and the $\mathrm{Be}$ atom density in the radial reflector. Model sensitivity to the oxygen atom density in the fuel and $\mathrm{BeO}$ atom density in an axial reflector was more than an order of magnitude lower than the previous sensitvities. Specific material sensitivities can be further subdivided into individual nuclides and reactions. The SNL analysis of individual nuclides and 
cross-sections indicated that the conceptual reactor model they studied was most sensitive to cross section and/or material density (mass) uncertainties for the ${ }^{235} \mathrm{U}$ fission and ${ }^{9} \mathrm{Be}$ scatter reactions.

The current LANL analysis begins with a similar sensitivity calculation based on density perturbation to identify what materials or components have the greatest impact on the model, followed by more detailed sensitivity analysis via individual cross section perturbation. This analysis seeks to determine the acceptable uncertainties in the various physics parameters to ascertain what additional data may be required to provide further confidence in a given reactor design. The LANL analysis will focus on materials that demonstrate the largest impact (sensitivity) for the FSP conceptual design. Preliminary LANL calculations implement a $\pm 2 \%$ change in density for the $\mathrm{UO}_{2}$ fuel, Be reflector, SS316 structural material and NaK coolant. Preliminary results confirm what was found in the SNL study: the FSP conceptual design is most sensitive to perturbations in the $\mathrm{UO}_{2}$ fuel and the beryllium reflector.

These results make no statement about the quantified uncertainty in cross sections or manufacturing tolerances and quality control for the fuel or reflector; results merely indicate that uncertainty in the parameters associated with these components will have the greatest effect on the overall bias in calculation of the reactor eigenvalues via calculations that apply arbitrary magnitude perturbations. The related reports that will be submitted on reactor testing and qualification will identify the physics parameters needed to qualify a reactor design and will quantify the desired accuracies for those parameters in general (Bailey, June 2011), and will quantify the sensitivity of the conceptual FSP design to specific perturbations in the various cross sections and material-dependent parameters (Poston, August 2011). The latter sensitivity analysis will apply perturbations based on the known uncertainties in the various physics parameters (cross sections, thermal scattering treatment parameters) and will also address the impact of manufacturing tolerances (e.g. uncertainty in material dimensions or straightness, material densities, isotopic composition, etc). Specific manufacturing tolerances on reactor module components and uncertainty in the characterization of the density and isotopic composition of the associated materials remain to be determined. Uncertainties in these values must be included in addition to uncertainties in the physics data in the overall evaluation of the results of a computational model to determine total bias in the calculation of core eigenvalues.

\section{I.B. $\quad$ The Value of Nuclear Testing to the FSP Design Evolution}

The overall purpose of testing and incorporation of validated test data in computational design is to develop technologies that will allow for a system design in which researchers are sufficiently confident, regarding design margins and value uncertainty for both nominal operation and postulated accident scenarios. Review of existing data from previous test programs can elucidate gaps in the database, or identify parameters for which the uncertainty in the data is sufficiently large as to cause unacceptable uncertainty in the overall FSP design. Testing and analysis early in the system design stage can provide identification of technology development needs and clarify technology development paths for future design optimization. Typically, a reactor is designed using a selected design tool (e.g. MCNP), and then a review of existing datasets and documented benchmarks is performed to support validation of the design tool. Alternately, one could choose to construct a design with consideration of the existing set of benchmarked data, such that the resulting design would have a high correlation with benchmarked data and, hence, reduced bias in the model calculations. [Additional detail on formal benchmarking of datasets is provided in section II.] 
Nuclear physics testing can provide information that is necessary to explore reactor design space and to perform effective design optimization. Although design optimization has not yet been performed for the FSP reactor concept, some basic generalities can be stated for small, compact reactors intended for space application. First, the system is characterized by a relatively small size and mass, such that it can be transported to its intended location using existing launch vehicles. Second, the reactor must be designed to meet all ground handling and launch safety requirements. The latter requirements take into account postulated accident scenarios; the reactor must be designed such that it will remain subcritical in all credible accident scenarios. Third, concept development should be kept within a reasonable, "affordable" cost. The latter requirement drives designers to the selection of a low-risk approach, which guides the selection of materials, components, and operating temperatures and takes into account historical applications and existing databases of operating characteristics.

\section{I.C. FSP Reference Concept}

The initial concept definition for the fission surface power system identifies key requirements for the reactor module and balance of plant [NASA 2010]. The report documents the "Pre-Phase A" FSP design, which will continue to evolve as requirements are better defined and hardware testing is completed. The preliminary reference concept includes a liquid-metal cooled, fast-spectrum reactor with Stirling power conversion and water-based heat rejection. The conceptual reactor module uses highly enriched $\mathrm{UO}_{2}$ fuel pins in a hexagonal core matrix with an external radial reflector and control drums; primary heat transfer from the core to the Stirling power convertors would be provided via a pumped liquid metal (sodiumpotassium ( $\mathrm{NaK})$ ) cooling loop. Reactivity control is accomplished via external $\mathrm{Be} / \mathrm{B}_{4} \mathrm{C}$ control drums, taking advantage of the high neutron leakage and resulting high reflector worth in an FSP-class reactor. Cost and development risk are reduced by adopting stainless steel for all core structure and coolant piping, and the beryllium reflector is encased in a stainless steel shell. Details and justification for the selection of these materials and components are included in [NASA 2010].

The current FSP reactor module reference concept includes the following materials and operating parameters [NASA 2010; Poston et al. 2009]:

- Minimum $40 \mathrm{kWe}$ net power, after all losses accounted;

- 8-year service life;

- Highly enriched uranium dioxide $\left(\mathrm{HEU}-\mathrm{O}_{2}\right)$ fuel;

- NaK-78 eutectic coolant;

- Fast spectrum (non-moderated) design;

- Be reflector;

- Rotating control drums with $\mathrm{B}_{4} \mathrm{C}$ control material (arcs);

- Stainless steel 316 (SS-316) clad and structural material;

- Subcritical in all postulated accident scenarios (e.g. water submersion or sand burial).

Note that many of the above specifications and material selections are the "preferred" options based on a number of selection criteria, but that other alternatives are available that may be capable of achieving the goals of the FSP system with similar development cost and schedule.

One of the primary criteria in space reactor design is that it remain subcritical during all credible, postulated accident scenarios. This criteria for subcriticality may be achieved in a number of ways: 
inclusion of spectral shift poisons (e.g. rhenium); inclusion of in-core safety control rods; or designing the core such that it has a very "high-worth" reflector. A reactor intended for space application differs from terrestrial systems in its reactivity requirements and options for reactivity control. The small size of the FSP core allows the design to meet sub-criticality requirements for all credible accident scenarios without an internal safety rod [NASA 2010]. A "high-worth" reflector can be used to keep the core size small, but also assists in meeting safety requirements. Spectral shift poisons, such as rhenium, may be used in conjunction with other reactivity control options; rhenium is not currently included in the FSP conceptual design.

\section{Applicable Critical Experiments}

Numerous reactor physics and criticality tests have been conducted to measure physics parameters, determine critical configurations, validate codes, etc. for simple configurations, highly flexible configurations, and for detailed reactor core designs. A review of the historical datasets was conducted, with a specific focus on those conducted for previous space reactor programs, fast spectrum reactors, and simple configurations incorporating materials relevant to the FSP design.

Key criteria used in the present study to reduce the list of potentially applicable datasets include:

- Use of highly enriched uranium (HEU) fuel, HEU-O ${ }_{2}$ fuel preferred;

- $\quad$ Use of $\mathrm{Be}$ or $\mathrm{BeO}$ reflector materials;

- $\quad$ Fast spectrum (non-moderated) for nominal operation, water moderated for accident analysis (submersion);

- Use of liquid metal coolant preferred.

These criteria are selected based on the current FSP conceptual design in attempt to reduce the large number of critical experiments data to a more manageable number. If the FSP design evolves significantly outside of these criteria (e.g. use of an alternate coolant, selection of a moderated design, etc.) additional evaluation of the available datasets may be prudent.

The current FSP conceptual design has a large length-to-diameter ratio $(\mathrm{L} / \mathrm{D}$, where $\mathrm{L}$ corresponds to the fueled length and $\mathrm{D}$ to the diameter of the fueled core region) as compared to that for many of the available datasets. Calculation of the L/D for specific benchmarked configurations is included below. The L/D for the FSP concept is approximately 2.6 in its present evolution [Poston et al. 2009]. A large L/D effectively increases the reactivity worth of the radial reflector, such that removal or replacement of the reflector in a postulated accident would cause the core reactivity to decrease. Computational analysis using MCNP5 1.51 and ENDF/B-VII.0 cross section evaluations indicates that this conceptual design meets sub-criticality requirements for all credible accident scenarios without including an internal safety rod. The large L/D design configuration may not be sufficiently validated by previous critical testing, as will be discussed.

Small fast spectrum reactors, such as the FSP, can be designed to have very high reflector worth to maximize safety in accident scenarios. Hence, the loss of a reflector in a postulated accident would cause the system to be subcritical, and replacement of that reflector with water or wet sand could not cause the reactor to become critical. The database of available criticality tests does not fully address reactor designs 
with very high reflector worth. However, this generalization is somewhat difficult to ascertain directly from the criticality benchmark reports (vs. benchmarks for measured reactor physics parameters). The reflector worth in each of these datasets may be calculated with a series of direct difference calculations using the model input decks included in the appendices for each benchmark report. This calculation has only been performed for the tested SP-100 reactor configurations at present (i.e. for ZPPR-20C).

In the current FSP concept, the radial and axial reflectors represent approximately $40 \%$ and $5 \%$ of the total reactivity worth in the system, respectively. These values are calculated by comparison of the eigenvalue determined with the reflector in place relative to voiding these regions in the MCNP model (direct difference calculation). For instance, the $\mathrm{k}_{\text {eff }}$ of the FPS conceptual design drops to approximately 0.6 when the radial reflector is removed. The reflector worth in the SP-100 design, as tested in the ZPPR$20 \mathrm{C}$ mock-up, was approximately $20 \%$ of the total worth $\left(\mathrm{k}_{\mathrm{eff}}=1.01356 \pm 0.00033\right.$ for the full configuration; $\mathrm{k}_{\mathrm{eff}}=0.80814 \pm 0.00040$ with all $\mathrm{Be}$ and $\mathrm{BeO}$ reflector material set to void in the MCNP as-built model). See section III.A for more discussion on the Zero Power Physics Reactor (ZPPR) criticality testing of the SP-100 design.

A highly-reflected, compact fast reactor exhibits two unique aspects relative to larger terrestrial fast reactors: (1) The reflector has a significant impact on dynamic performance. In some cases, the temperature coefficient of reactivity feedback for the radial reflector is higher than that of the fuel, and the thermal time constant for the reflector is significantly longer than that of other core components. Hence, the reflector temperature and expansion effects must be modeled individually. (2) Core neutrons leak into the reflector, and are then reflected back into the core, such that "reflected neutrons" have a much longer lifespan than in-core neutrons. This delayed neutron group is referred to as "geometric delayed neutrons." Because of the nature of the geometric delayed neutron group, these neutrons have lifespans that are orders-of-magnitude greater than neutrons that do not leak out of the core. Additionally, these neutrons have higher "worth" than in-core neutrons due to moderation as the neutrons travel through the reflector and back into the core [NASA 2010]. The impact of the geometric delayed neutron group can be seen in the MCNP calculation results for the FSP concept, which shows flux peaking in the outer ring of fuel elements due to reflected neutrons [Poston, et al. 2009].

As the reflector thickness increases, the impact of the reflected neutrons on interactions in the fueled region of core also increases, resulting in greater bias in the corresponding eigenvalue calculations. The increased bias is partially due to uncertainties in the physics interactions governing production of the neutrons from the reflector region (e.g. uncertainty in the beryllium scatter cross section), but may also be due to geometric effects and travel time of neutrons in the reflector region and back into the fueled region of the core. Although improvement in the uncertainties associated with the physics effects will improve the overall calculation bias, improved physics data will not provide further clarification of the geometry effects. Hence, it is anticipated that a cold critical experiment may still be required for an FSP-like configuration.

Tables 1 - 5 summarize datasets that are potentially applicable to an FSP-class reactor, as specified in the initial concept definition. Each table entry specifies the materials used in the test configuration, measured parameters, associated references, and the status of any benchmarking of the experiments. The International Criticality Safety Benchmarking Evaluation Project (ICSBEP) [Briggs, Scott 2003] has 
undertaken the task of benchmarking a large number of previously acquired data sets for which sufficient information exists on the precise test configurations. Although not all of the potentially applicable experiments have been benchmarked, some are slated for benchmarking in the near future and some have sufficient information in the corresponding reports to still be of use to the FSP program. More comprehensive details of available criticality benchmarks can be obtained from the ICSBEP Handbook [OECD-NEA 2010].

One of the methods to check the accuracy of neutron transport codes and cross section data sets used in the modeling and design of nuclear systems is to test them with well characterized experimental configurations. Models of these configurations become benchmarks for code validation to test specific neutronic parameters and to refine cross section libraries. A typical benchmark evaluation is divided into four sections [Dean 2003]:

1. Detailed Description of the Experiment

A complete, detailed description of experimental data, including method of measurement, dimensions, and material compositions and their associated uncertainties.

\section{Evaluation of Experimental Data}

Assessment of the experimental data, including inconsistent or inconclusive data and evaluation of both reported and unreported uncertainties.

3. Benchmark Model Specifications

A benchmark model of the experiment is fully described and characterized.

\section{Results of Sample Calculations}

Sample calculations with common codes and cross section data are provided, with example input listings provided in the appendix.

The method described above is applied only to the calculation of $\mathrm{k}_{\mathrm{eff}}$ in ICSBEP benchmarks. A separate International Reactor Physics Experiment Evaluation Project (IRPhEP) was established to benchmark more complex systems with their reactor physics parameters using the aforementioned benchmark format [Bess, Briggs 2010]. Additional types of integral measurements include buckling, spectral characteristics, reactivity effects, reactivity coefficients, kinetics measurements, reaction-rate and power distributions, nuclide compositions such as fuel burnup, and other miscellaneous measurements. Reactor physics benchmarks are available in the IRPhEP Handbook [OECD-NEA 2011].

Benchmarks included in either the ICSBEP or IRPhEP Handbooks undergo thorough peer review prior to acceptance and publication. Several of the ICSBEP benchmark experiments were found to be applicable to small, fast spectrum fission reactor design; however, none of the benchmarks currently included in the IRPhEP Handbook were found to be applicable. Additional experiments are being added to the handbooks each year, such that future evaluations of space nuclear reactor designs should assess any recent additions to the handbooks for applicability.

Potentially applicable benchmarks were previously identified by researchers at LANL, INL, ORNL and SNL [Marcille 2004; Weaver 2007; Parry, et al. 2008; informal draft report by Harms and Barber 2009]. The benchmarks identified in those studies considered similarity to the conceptual JIMO reactor module [Marcille 2004] or to the then-current version of the FSP conceptual design, where the latter analyses 
considered use of a significant amount of Be in the benchmark configuration and simplicity in the benchmark geometry [Weaver 2007; Harms and Barber 2009]. Many of the identified benchmarks are incorporated in the summary tables below, categorized as noted.

\section{Data Sets Included in Table 1, Be-reflected Space Reactors}

Two of the criticality experiments associated with the TOPAZ-II (Enisey) space reactor, performed in the early 1990s. Benchmarks have been completed for the postulated accident scenario cases, namely water immersion and sand burial. These datasets may be useful to the analysis of postulated accident scenarios for the FSP concept based on the similarity in fuel and reflector characteristics; however, this reactor design incorporated $\mathrm{ZrH}$ moderating material, lowering the neutron energy spectrum to the epithermal regime. Hence, the applicability of these benchmarks to the FSP model may be limited due to the differences in fast vs. moderated core physics. Information available in the benchmark reports indicate that the TOPAZ-II design had an L/D of $\sim 1.8$, based on a maximum fuel element height of $375 \mathrm{~mm}$ (some elements were $325 \mathrm{~mm}$, some $375 \mathrm{~mm}$ ) and a moderator block diameter of $210 \mathrm{~mm}$. The reflector worth has not been calculated for the benchmarked datasets to date, but sufficient information should be available in the input deck listings provided with the benchmark reports.

None of the experiments performed as a part of the Space Nuclear Auxiliary Power (SNAP) reactor program have been benchmarked to date. The SNAP reactors operated with an epithermal neutron spectrum, as they incorporate HEU-ZrH fuel. Hence, the core physics measurements in these test series are not likely to be useful to the current FSP effort, but the reflector and control drum ( $\mathrm{BeO}$ and $\mathrm{Be})$ worth measurements may provide useful information for benchmarking current modeling codes. The various reactors designed and tested in the SNAP series all incorporated the HEU-ZrH fuel and NaK coolant, but considered different power levels and design configurations. The SNAP-2 design had an approximate L/D of 0.9 [Jarrett 1973], SNAP-10a had L/D 1.8, and SNAP-8ER (S8ER, experimental reactor) had an $\mathrm{L} / \mathrm{D} \sim 1.5$. The fuel length in the S8DR (developmental reactor) was increased by 2-in. relative to S8ER to yield an L/D of $\sim 1.8$ [Staub 1973].

The Lithium Cooled Reactor Experiment (LCRE) performed in 1964 incorporated $\mathrm{HEUO}_{2}-\mathrm{BeO}$ fuel, $\mathrm{BeO}$ reflectors, and lithium coolant. The fuel was enriched to $97.3 \%{ }^{235} \mathrm{U}$, and the various critical assemblies that were tested included $\mathrm{Al}_{2} \mathrm{O}_{3}, \mathrm{BeO}$, niobium and stainless steel. As noted for other experimental configurations, the LCRE L/D was significantly less than that for the FSP reactor, on the order of 1.1 to 1.2. However, test configurations did address varying reflector thicknesses such that three different uranium-to-BeO ratios were studied. Hence, these configurations may prove to be useful in benchmarking small, fast spectrum reactor cores. These datasets are not currently benchmarked; if sufficient information on the test configuration exists in the test report [Paradia et al. 1964], calculation of the reflector worth in each tested configuration will be useful in determining their applicability / similarity to the conceptual FSP design.

\section{Data Sets Included in Table 2, BeO-reflected Space Reactors}

The SP-100 design ( $\sim 1980$ s timeframe) was the most recent U.S. space reactor design to undergo significant nuclear testing for determination of reactor physics parameters and criticality. The SP-100 was a fast spectrum reactor design that incorporated thermoelectric power conversion to produce $100 \mathrm{kWe}$ ( $\sim 4 \%$ conversion efficiency). The SP-100 design, at the time of project termination, employed pin-type 
UN fuel with a Re-lined $\mathrm{Nb}$ alloy clad and lithium coolant. The core L/D was approximately 1.2 [Truscello and Rutger 1992]. The SP-100 design was tested in nominal and postulated accident scenarios using a flexible split table and drawer configuration at the Zero Power Physics Reactor (ZPPR) test facility in Idaho. Key experiments from the SP-100-related critical experiments (ZPPR-20) have been benchmarked and may be useful in qualifying an FSP reactor design. As noted in the introduction to this section, the reflector worth in the ZPPR-20C configuration was $\sim 20 \%$. More details on the ZPPR-20 experiments are included in section III.A.

\section{Data Sets Included in Table 3, HEU Fast Reactor Experiments}

Earlier testing at the Idaho Zero Power Reactor (ZPR, which later became the ZPPR facility) measured criticality and reactor physics data for several highly enriched uranium, fast spectrum reactor assemblies (among many other tested assemblies not applicable to the current project). As noted in Table 3, the ZPR-9 test series incorporated HEU metal fuel. The 9/7, 8, and 9 variants were also BeO reflected, whereas the ZPR-9/34 configuration was stainless steel reflected. These benchmarks may prove useful, as they have many materials in common with the FSP concept and were operated with a fast neutron spectrum.

\section{Data Sets Included in Table 4, Additional Related Experiments}

The Special Power Excursion Reactor Test (SPERT) experiments incorporated both slightly enriched and highly enriched uranium fuels. Although these experiments relate to a water-moderated reactor design rather than a fast spectrum system, they may be useful in understanding space reactor performance in a water immersion accident.

The Los Alamos experiment performed on the Planet split table may prove useful in investigating the effect of including rhenium in the FSP design (benchmark HEU-MET-THERM-033). This experiment incorporated HEU foils and polyethylene moderator, such that it may provide data appropriate to benchmarking reactor modeling in postulated FSP accident scenarios (e.g. water immersion). Rhenium has been used in various conceptual reactor designs as a spectral shift absorber to offset reactivity increases that can result from water submersion in postulated accident scenarios [King and El-Genk, 2006; Poston, 2002; El-Genk and Tournier, 2004a, 2004b; Truscello and Rutger 1992]. At present no decision has been made regarding inclusion of rhenium in the FSP reactor design.

\section{Data Sets Summarized in Table 5, Simple Configurations}

Many of the benchmarked data sets within the ICSBEP Handbook involve relatively simple configurations that are easy to model and for which the effects of individual components and variations can be easily evaluated. Many of these benchmarked datasets were identified by Weaver [2007]. Simple configurations such as these may be useful in evaluating the uncertainty in the FSP design, or additional simple configurations demonstrating high correlation with an FSP-class reactor concept could be designed to support the reactor design evolution and optimization.

A simplified experiment configuration incorporating $\mathrm{HEU}-\mathrm{O}_{2}$, Be reflector, and SS-347 cladding, conducted at ORNL in the 1960s [Milhalczo 1963] is due to be benchmarked in 2013. This simple configuration incorporated numerous measurements, as noted in Table 5, and may be useful in qualifying a small, Be-reflected fast spectrum reactor as is being considered for the FSP reactor. The tested core L/D 
was on the order of 1.17, such that the reflector worth likely was not as large as in the conceptual FSP design. The overall applicability of this dataset remains to be determined following the ICSBEP evaluation.

Benchmark HEU-MET-FAST-005 was completed for criticality of Be- and Mo-reflected cylinders of HEU in 1999. Six cases were studied in all, with variations made to the fuel loading, reflector thickness, and placement of Be reflector and Mo tubes. The system L/D was on the order 1.35. At this time, the corresponding physics benchmark does not exist. Sufficient data is available in the criticality benchmark to assess the corresponding physics data, including reflector worth. However, the original experiment report referenced in the benchmark will be required for comparison of calculated to experimentally determined reflector worth. (Note: The benchmark report references a Russian preprint report; the ICSBEP analysis team will be contacted for further information on the availability of this experiment report.)

The 2009 SNL study by Harms and Barber evaluated eight criticality benchmarks for applicability to the FSP conceptual design [Poston et al. 2008], calculating the level of correlation for the various tested configurations. Benchmarks were selected based on their incorporation of a significant amount of beryllium in the benchmarked configuration and overall simplicity of the benchmark. Several global and reaction-specific indices were calculated for the FSP and benchmarked configurations. The $c_{k}$ global correlation coefficient can be used to determine correlation between uncertainties in the FSP design and the benchmarked designs, including sensitivities to all reaction types and covariances. Nuclide-specific correlation (g index) was calculated for the most significant nuclides and interactions, specifically Be scatter and ${ }^{235} \mathrm{U}$ fission. Based on these indices, it was determined that benchmarks HEU-MET-FAST041, -058, and -066 (included in Table 5; datasets noted as HMF41, HMF58, and HMF66) bore the greatest similarity to the FSP design. Each of these benchmarks demonstrated a $c_{k}>0.95$ and had at least one configuration with $\mathrm{g}>0.95$ for Be; HMF66 also demonstrated $g>0.95$ for ${ }^{235} \mathrm{U}$. Benchmark HEUMET-FAST-077, which evaluates a continuation of the Nimbus experiment series covered in -058 and 066, has been approved for publication but has not yet been published in the ICSBEP Handbook. This benchmark bears sufficient similarity to the configurations of -058 and-066 that it is expected to show similar applicability to the FSP design. The 2009 analysis used MCNP5.1.40 with ENDF/B-VI.8 and ENDF/B-VII.0 cross sections.

Many of the other configurations provided in Table 5 were also designed as simple spherical or cylindrical geometries to test interactions between HEU and reflecting and/or moderating material such as $\mathrm{Be}, \mathrm{BeO}$, polyethylene, and steel. Correlation coefficients between these configurations and the FSP design have not been calculated. Simple benchmark experiments can be used to validate fundamental cross section data without the complexity of a larger reactor system. Specific design of a set of benchmarks using fairly simple geometries could demonstrate an even higher correlation $\left(c_{k}\right)$ with the FSP design than those evaluated by Harms and Barber. These configurations could incorporate nesting HEU metal and beryllium shells (if materials in this form are still available) and could be tested at the LANL Critical Experiments Facility (CEF) at the Device Assembly Facility (DAF), located at the Nevada Test Site (NTS). Discussion on potential test facilities is included in section IV. 


\begin{tabular}{|c|c|c|c|c|}
\hline Data Source & Design Basics & Measurements & Documentation & Benchmark \\
\hline $\begin{array}{l}\text { TOPAZ-II Water } \\
\text { Immersion Accidents }\end{array}$ & $\begin{array}{l}\mathrm{HEU}-\mathrm{O}_{2} \text { Fuel }(\sim 96 \% \\
\text { enriched }) \\
\text { Be \& BeO Reflected } \\
\mathrm{ZrH} \text { Moderated } \\
\mathrm{B}_{4} \mathrm{C} \text { Control Drums } \\
\text { Mock-up of TFE } \\
\text { structure }\end{array}$ & $\begin{array}{l}6 \text { Critical Experiments to } \\
\text { Simulate Water Immersion } \\
\text { Accidents } \\
\text { (studied effect of replacing } \\
\text { Be and } \mathrm{BeO} \text { with water or } \\
\text { void) }\end{array}$ & $\begin{array}{l}\text { J. Sapir, et al., "Pre-Orbital Criticality Safety for the } \\
\text { NEPST Mission," } 11^{\text {th }} \text { Symposium on Space Power and } \\
\text { Propulsion (1994). }\end{array}$ & $\begin{array}{l}\text { HEU-COMP- } \\
\text { MIXED-003 }\end{array}$ \\
\hline $\begin{array}{l}\text { TOPAZ-II Sand / Water } \\
\text { Immersion Accidents }\end{array}$ & $\begin{array}{l}\mathrm{HEU}-\mathrm{O}_{2} \text { Fuel } \\
\mathrm{Be} \& \mathrm{BeO} \text { Reflected } \\
\mathrm{ZrH} \text { Moderated } \\
\mathrm{B}_{4} \mathrm{C} \text { Control Drums }\end{array}$ & $\begin{array}{l}5 \text { Critical Experiments to } \\
\text { Simulate Sand / Water } \\
\text { Immersion Accidents }\end{array}$ & $\begin{array}{l}\text { Ye. S. Glushkov, et al., "Water/Sand Flooded and } \\
\text { Immersed Critical Experiment and Analysis Performed in } \\
\text { Support of the TOPAZ-II Safety Program," } 12^{\text {th }} \\
\text { Symposium Space Nuclear Power and Propulsion (1995). }\end{array}$ & $\begin{array}{l}\text { HEU-COMP- } \\
\text { MIXED-004 }\end{array}$ \\
\hline $\begin{array}{l}\text { TOPAZ-II Dry Critical } \\
\text { Experiments }\end{array}$ & $\begin{array}{l}\mathrm{HEU}-\mathrm{O}_{2} \text { Fuel } \\
\mathrm{Be} \& \mathrm{BeO} \text { Reflected } \\
\mathrm{ZrH} \text { Moderated } \\
37 \text { simulated TFEs } \\
\text { No NaK coolant in } \\
\text { crit assembly }\end{array}$ & $\begin{array}{l}\text { Narciss M-II facility at } \\
\text { Kurchatov Institute }\end{array}$ & $\begin{array}{l}\text { D.B. Pelowitz, J. Sapir, and E.S. Glushkov, "Dry Critical } \\
\text { Experiments and Analyses Performed in Support of the } \\
\text { TOPAZ-2 Safety Program," } 12^{\text {th }} \text { Symposium Space } \\
\text { Nuclear Power and Propulsion (1995). } \\
\text { S.S. Voss, “TOPAZ II System Description," LA-UR-94-4 } \\
\text { (1994). (OSTI 17255) } \\
\text { S.S. Voss and E.A. Rodriguez, "Russian Topaz II System } \\
\text { Test Program (1970-1989), LA-UR-93-3398 (1993). (OSTI } \\
\text { 17450) }\end{array}$ & NA \\
\hline $\begin{array}{l}\text { Thermionic Reactor } \\
\text { Critical Experiments } \\
\text { (TRCE) }\end{array}$ & $\begin{array}{l}\mathrm{HEU} \text { Metal Rods } \\
\mathrm{WO}_{3} \& \mathrm{Al}_{2} \mathrm{O}_{3} \text { Rods } \\
\mathrm{Be} / \mathrm{BeO} \text { Reflected } \\
\mathrm{Al} \mathrm{Clad}\end{array}$ & $\begin{array}{l}\text { Criticality, additional } \\
\text { measurements unknown }\end{array}$ & $\begin{array}{l}\text { J.F. Kunze, et al., "Thermionic Reactor Critical Experiment } \\
\text { Data Report," GEMP-423, General Electric (1966). } \\
\text { S.C. Cohen, et al., "Fast Critical Experiments in Support of } \\
\text { Thermionic Reactor Physics," GA-8767 (1968). (OSTI } \\
\text { 40101068) } \\
\text { G.F. Niederauer, "Analyzing the Thermionic Reactor } \\
\text { Critical Experiments," NASA-TM-X-2925 (1973). }\end{array}$ & NA \\
\hline $\begin{array}{l}\text { SNAP-2 Developmental } \\
\text { Reactor }\end{array}$ & $\begin{array}{l}\text { Fully enriched-U } \\
\text { fueled, } \mathrm{H} \text { mod. } \\
\text { Be-reflected } \\
\text { Be control drums } \\
\text { Be safety elements } \\
\text { NaK coolant, NaK- }\end{array}$ & $\begin{array}{l}\text { Critical loading } \\
\text { Safety and Control Drum } \\
\text { worth } \\
\text { H importance msmt } \\
\text { Worth of Cd core liner } \\
\text { Coolant worth }\end{array}$ & $\begin{array}{l}\text { "Final Report on the SNAP } 2 \text { Development Reactor } \\
\text { (S2DR) Test Program," NAA-SR-8295 (1964). (OSTI } \\
\text { 18923) } \\
\text { A.A. Jarrett, "SNAP 2: Summary Report," AI-AEC-12068 } \\
\text { (1973). (OSTI 40100889) }\end{array}$ & NA \\
\hline
\end{tabular}




\begin{tabular}{|c|c|c|c|c|}
\hline Data Source & Design Basics & Measurements & Documentation & Benchmark \\
\hline & to-NaK HX & $\begin{array}{l}\text { Isothermal } \mathrm{T} \text { and } \mathrm{P} \text { coeff. } \\
\text { Power transients (dry and } \\
\text { w/coolant) }\end{array}$ & & \\
\hline $\begin{array}{l}\text { SNAP-8 Experimental } \\
\text { Reactor (S8ER) - } \\
\text { Dry Critical } \\
\text { Experiments }\end{array}$ & $\begin{array}{l}\text { 93.5\% enr U-ZrH } \\
\text { fuel / moderator } \\
\text { Be external reflector } \\
\mathrm{BeO} \text { internal reflector } \\
\mathrm{SS} 316 \text { vessel } \\
\text { Hastelloy-N clad } \\
\mathrm{NaK} \text { coolant and } \\
\text { power conversion not } \\
\text { included }\end{array}$ & $\begin{array}{l}\text { Dry critical experiments: } \\
\text { Critical fuel loading for } \\
\text { various reflector } \\
\text { thicknesses/drum configs; } \\
\text { Radial reflector worth; } \\
\text { control drum worth; } \mathrm{BeO} \\
\text { internal reflector worth; } \\
\mathrm{Sm}_{2} \mathrm{O}_{3} \text { worth; B worth at core } \\
\text { center }\end{array}$ & $\begin{array}{l}\text { D.E. Crouter, "SNAP } 8 \text { Experimental Reactor Critical } \\
\text { Experiment,” NAA-SR-9642 (1964). (OSTI 19129) } \\
\text { D.S. Brinkman and V.L. Rooney, "SNAP } 8 \text { Experimental } \\
\text { Reactor, A Description,” NAA-SR-7261 (1962). (OSTI } \\
\text { 18854) } \\
\text { L.M. Fead, et al., "SNAP } 8 \text { Experimental Reactor } \\
\text { Operations and Test Results,” NAA-SR-10903 (1965). } \\
\text { (OSTI 19346) } \\
\text { D.G. Mason, "SNAP } 8 \text { Design Description,” NAA-SR- } \\
\text { MEMO-8750 (1963). (OSTI 21732) } \\
\text { "SNAP } 8 \text { Summary Report,” AI-AEC-13070 (1973). } \\
\text { (OSTI } 40102321 \text { ) }\end{array}$ & NA \\
\hline $\begin{array}{l}\text { SNAP-8 Experimental } \\
\text { Reactor (S8ER) - } \\
\text { Physics measurements + } \\
\text { criticality }\end{array}$ & $\begin{array}{l}\text { 93.5\% enr U-ZrH } \\
\text { fuel / moderator, } \\
\text { Hast-N clad, } \mathrm{Sm}_{2} \mathrm{O}_{3} \\
\text { burnable poison, } \\
\mathrm{SS} 316 \text { core vessel, } \\
\mathrm{NaK} \text { coolant, } \mathrm{BeO} \\
\text { internal reflector } \\
\text { w/Hast-N clad, Be } \\
\text { control drums }\end{array}$ & $\begin{array}{l}\text { Power and isothermal T } \\
\text { coefficients; T defect; } \\
\text { poisoning effects; H loss } \\
\text { reactivity effects; NaK } \\
\text { reactivity effect, criticality, } \\
\text { reflector thickness, control } \\
\text { rod worths, moderator to fuel } \\
\text { ratio effects, special material } \\
\text { worths, internal reflector } \\
\text { worths, power density } \\
\text { distribution }\end{array}$ & $\begin{array}{l}\text { Fead, L.M.; Felten, L.D.; Rooney, V.L., "SNAP } 8 \\
\text { Experimental Reactor Operations and Test Results," NAA- } \\
\text { SR-10903 (1965). (OSTI 19346) } \\
\text { D.S. Brinkman and V.L. Rooney, “SNAP } 8 \text { Experimental } \\
\text { Reactor, A Description,” NAA-SR-7261 (1962). (OSTI } \\
\text { 18854) } \\
\text { D.E. Crouter, “SNAP } 8 \text { Experimental Reactor Critical } \\
\text { Experiment,” NASS-SR-9642 (1964). (OSTI 19129) } \\
\text { D.G. Mason, "SNAP 8 Design Description,” NAA-SR- } \\
\text { MEMO-8750 (1963). (OSTI 21732) } \\
\text { "SNAP } 8 \text { Summary Report,” AI-AEC-13070 (1973). } \\
\text { (OSTI } 40102321 \text { ) }\end{array}$ & NA \\
\hline $\begin{array}{l}\text { SNAP-8 Developmental } \\
\text { Reactor (S8DR) }\end{array}$ & $\begin{array}{l}\text { 316SS core vessel } \\
\text { Hastelloy C lower } \\
\text { grid plate; } 316 \mathrm{SS} \\
\text { upper plate } \\
\text { Enr. U-ZrH fuel } \\
\text { Be reflector }\end{array}$ & $\begin{array}{l}\text { Start-up reliability, hot } \\
\text { performance checks }\end{array}$ & $\begin{array}{l}\text { W.J. Kurzeka, "Functional Design Description and Test } \\
\text { Summary of the SNAP } 8 \text { Development Reactor Mockup- } \\
1, \text {, NAA-SR-12300, SNAP Reactor, SNAP Program, M- } \\
3679\left(51^{\text {st }} \text { Ed) (1967). (OSTI 19588) } \rightarrow \text { Does not include }\right. \\
\text { criticality testing. } \\
\text { L.D. Swenson, "S8DR Core Performance Evaluation, }\end{array}$ & $\mathrm{NA}$ \\
\hline
\end{tabular}




\begin{tabular}{|c|c|c|c|c|}
\hline Data Source & Design Basics & Measurements & Documentation & Benchmark \\
\hline & $\begin{array}{l}\text { Inconel } \mathrm{X} \text { reflector } \\
\text { support structure }\end{array}$ & & $\begin{array}{l}\text { NAA-SR-12482, SNAP Reactor, SNAP Program, M-3679 } \\
\left(51^{\text {st }} \text { Ed) (1967). - study performed following S8ER test to }\right. \\
\text { re-visit elements of the S8DR analysis that was performed } \\
\text { prior to testing, which experienced excessive fuel swelling } \\
\text { and fuel clad cracking } \\
\text { Locate: } \\
\text { P.S. Olson, et al., "In-Pile Behavior of SNAP } 8 \\
\text { Experimental Reactor Type Sublength Fuel Elements } \\
\text { (NAA-115-1 Experiment)," NAA-SR-11996, Nov 25, } 1966 \\
\text { (CRD). } \\
\text { M.D. O’Neill, “S8ER Wet Critical Configuration Test } \\
\text { S8ER-007,” NAA-SR-9755 Revised, April 2, 1963 (CRD). } \\
\text { D.G. Mason, “SNAP 8 Design Description,” NAA-SR- } \\
\text { MEMO-8750 (1963). (OSTI 21732) } \\
\text { L.D. Felten and H.D. May, "Summary of SNAP } 8 \\
\text { Developmental Reactor (S8DR) Operations,” AI-AEX- } \\
\text { 13071 (1973). (OSTI 40100891) } \\
\text { "SNAP 8 Summary Report,” AI-AEC-13070 (1973). } \\
\text { (OSTI 40102321) }\end{array}$ & \\
\hline SNAP-10A & $\begin{array}{l}\text { U-ZrH fuel, } \mathrm{NaK} \\
\text { coolant }\end{array}$ & $\begin{array}{l}\text { Critical testing / operation of } \\
\text { duplicate unit, FS-3: } \\
\text { Dry critical (Sept 1964) } \\
\text { Start-up to power (Jan 1965), } \\
\text { one yr at full power } \\
\text { SNAPSHOT Acceptance } \\
\text { Testing: CD calibration, } \\
\text { reactivity worths, temperature } \\
\text { coefficients }\end{array}$ & $\begin{array}{l}\text { **Transient testing in SNAPTRAN series; details on } \\
\text { previous critical assemblies not found } \\
\text { D.W. Staub, "SNAP 10A Summary Report," NAA-SR- } \\
12073 \text { (1967). (OSTI 17027) } \\
\text { A.R. Daynes, et al., "SNAP 10A Reactor Nuclear } \\
\text { Analysis," NAA-SR-9754 (1965). (OSTI 19127) } \\
\text { J. Susnir and T. Harman, "SNAP 10A Reactor Design } \\
\text { Summary,” NAA-SR-MEMO-8679 (1963). (OSTI 21733) } \\
\text { W.W. Davis and J. Susnir, "SNAP 10A Reactor Design } \\
\text { Summary, Revision 1,” NAA-SR-MEMO-8679(Rev.1) } \\
\text { (1964). (OSTI 21738) }\end{array}$ & NA \\
\hline SNAPTRAN-1 & $\begin{array}{l}\text { SNAP-10A Critical } \\
\text { assembly }\end{array}$ & $\begin{array}{l}\text { Ratio of } \beta_{\text {eff }} \text { to prompt } \\
\text { neutron lifetime }\left(\beta_{\text {eff }} / \ell^{*}\right)\end{array}$ & $\begin{array}{l}\text { R.L. Randall and G.R. Grayban, "SNAPTRAN-1 Testing," } \\
\text { NAA-SR-MEMO } 9160 \text { (1963). (OSTI 21595) }\end{array}$ & NA \\
\hline
\end{tabular}




\begin{tabular}{|c|c|c|c|c|}
\hline Data Source & Design Basics & Measurements & Documentation & Benchmark \\
\hline SNAPTRAN-1 and -2 & $\begin{array}{l}\text { SNAPTRAN-1: } \\
\text { SNAP 10A/2 core \& } \\
\text { Be reflector } \\
\text { SNAPTRAN-2: } \\
\text { destructive test }\end{array}$ & $\begin{array}{l}\text { Purpose: detailed study of } \\
\text { prompt } n \text { kinetics of SNAP } \\
\text { core } w / \text { Be reflector } \\
\text { Drum reactivity, prompt } \\
\text { temperature coefficient, } \\
\text { prompt n generation time, } \\
\text { power profile }\end{array}$ & $\begin{array}{l}\text { J.F. Jackson, W.F. Rhoades, and L.I. Moss, "Analysis of } \\
\text { SNAPTRAN-1 and -2 Reactor Kinetics Experiments," } \\
\text { NAA-SR-11850 (June 1967). (OSTI 19429) } \\
\text { **non-destructive test series for basic kinetics data }\end{array}$ & \\
\hline $\begin{array}{l}\text { SNAPTRAN-10A/2-1 } \\
\text { Critical Assembly }\end{array}$ & & Critical Loading & $\begin{array}{l}\text { R.P. Johnson, "SNAPTRAN 10A/2-1 Critical Assembly," } \\
\text { NAA-SR-MEMO-10660 (Nov 1964). (OSTI 21783) }\end{array}$ & \\
\hline SNAP-50 & $\begin{array}{l}\text { UC Fuel, } 93.2 \%{ }^{235} \mathrm{U} \\
\text { Various reflector } \\
\text { configurations - } \\
\mathrm{BeO}, \mathrm{CH}_{2} \\
\mathrm{~B}_{4} \mathrm{C} \text { control rods }\end{array}$ & $\begin{array}{l}\text { Criticality - critical mass } \\
\text { with varying reflector } \\
\text { thicknesses; reactivity control } \\
\text { Material reactivity } \\
\text { coefficients } \\
\text { Fission rate distributions }\end{array}$ & $\begin{array}{l}\text { R. C. Callen, P.S. Check, R.E. Kearney, and W.F. Welsh, } \\
\text { SNAP-50 Critical Experiments and Analysis, Pratt \& } \\
\text { Whitney Aircraft, PWAC-487 (September 1965). (OSTI } \\
\text { 22157) }\end{array}$ & \\
\hline $\begin{array}{l}\text { Lithium Cooled Reactor } \\
\text { Experiment (LCRE) }\end{array}$ & $\begin{array}{l}\mathrm{HEUO}_{2} \text {-BeO Fuel } \\
\mathrm{BeO} \text { Reflectors } \\
\text { Lithium Coolant }\end{array}$ & $\begin{array}{l}\text { Criticality, reactivity, fission } \\
\text { rates, gamma heating, control } \\
\text { worths }\end{array}$ & $\begin{array}{l}\text { "Reactor Operations Final Report Lithium-Cooled Reactor } \\
\text { Experiment," PWAC-408 (1964). (OSTI 22050) } \\
\text { E.L. Paradia, et al., "LCRE Critical Experiments," PWAC- } \\
404 \text { (1964). (OSTI 22149) }\end{array}$ & NA \\
\hline
\end{tabular}




\begin{tabular}{|c|c|c|c|c|}
\hline Data Source & Design Basics & Measurements & Documentation & Benchmark \\
\hline $\begin{array}{l}\text { Zero Power Physics } \\
\text { Reactor (ZPPR)-20, A-F } \\
\text { (SP-100 test series, } \\
\text { operational and accident } \\
\text { conditions) }\end{array}$ & $\begin{array}{l}\text { HEU Metal } \\
\text { BeO Reflected } \\
\mathrm{Nb} / \mathrm{Zr} / \text { Re Clad } \\
\mathrm{Li} \mathrm{Coolant} \\
\mathrm{Be} / \mathrm{LiH} / \mathrm{W} \text { Flight } \\
\mathrm{Shield} \\
\text { Enr. }{ }_{4} \mathrm{C} \text { Control } \\
\text { Rods }\end{array}$ & $\begin{array}{l}\text { Critical eigenvalue, } \\
\text { reaction rate distributions, } \\
\text { internal control rod } \\
\text { worths, radial reflector } \\
\text { worths, Li void worth }\end{array}$ & $\begin{array}{l}\text { C.A. Porter, S.V. Andre, R.A. Doncals, "SP-100 Critical } \\
\text { Experiments Final Validation Report,” SP-RPT-90-051, } \\
\text { Westinghouse Electric Corporation (1990). } \\
\text { Note: Includes evaluation of results with MCNP, } \\
\text { ENDF/B-V data libraries. }\end{array}$ & \begin{tabular}{|l} 
Some \\
Configurations \\
Evaluated (See \\
Below)
\end{tabular} \\
\hline $\begin{array}{l}\text { Zero Power Physics } \\
\text { Reactor (ZPPR)-20C } \\
\text { (SP-100 Reference } \\
\text { Flight Configuration) }\end{array}$ & \begin{tabular}{|l|}
$\mathrm{HEU}$ Metal \\
$\mathrm{BeO}$ Reflected \\
$\mathrm{Nb} / \mathrm{Zr} /$ Re Clad \\
Depleted-Li \& Na \\
Coolant \\
$\mathrm{W} /$ Be/B-Poly Flight \\
Shield \\
$\mathrm{B}_{4} \mathrm{C}$ Control Rods \\
\end{tabular} & $\begin{array}{l}\text { Criticality, shim rod } \\
\text { calibrations, reaction rates, } \\
\text { gamma heating, control } \\
\text { rod worths, reflector } \\
\text { worths, flight shield worth }\end{array}$ & $\begin{array}{l}\text { D.N. Olsen, et al., "Experiments for the SP-100 Space } \\
\text { Reactor in ZPPR-20," INL/EXT-05-00556 \& ANL- } \\
\text { ZPR-497 (2005). } \\
\text { D.N. Olsen, et al., "Configurations for SP-100 } \\
\text { Experiments in ZPPR-20,” INL/EXT-05-00558 \& ANL- } \\
\text { ZPR-498 (2005). }\end{array}$ & $\begin{array}{l}\text { HEU-MET-FAST- } \\
075 \text { (Criticality } \\
\text { only) }\end{array}$ \\
\hline $\begin{array}{l}\text { Zero Power Physics } \\
\text { Reactor (ZPPR)-20D } \\
\text { (SP-100 Critical Water } \\
\text { Immersion Accident) }\end{array}$ & \begin{tabular}{|l}
$\mathrm{HEU}$ Metal \\
$\mathrm{BeO}$ Reflected \\
$\mathrm{Nb} / \mathrm{Zr} /$ Re Clad \\
Depleted-Li \& Na \\
Coolant \\
W/Be/B-Poly Flight \\
Shield \\
$\mathrm{B}_{4} \mathrm{C}$ Control Rods \\
\end{tabular} & $\begin{array}{l}\text { Simulated water } \\
\text { immersion criticality, gap } \\
\text { worth, shim rod } \\
\text { calibrations, fuel safety } \\
\text { rod worths, fuel/Re/Nb } \\
\text { radial and axial material } \\
\text { worths, control rod worths, } \\
\text { reflector worths }\end{array}$ & $\begin{array}{l}\text { D.N. Olsen, et al., "Experiments for the SP-100 Space } \\
\text { Reactor in ZPPR-20," INL/EXT-05-00556 \& ANL- } \\
\text { ZPR-497 (2005). } \\
\text { D.N. Olsen, et al., "Configurations for SP-100 } \\
\text { Experiments in ZPPR-20,” INL/EXT-05-00558 \& ANL- } \\
\text { ZPR-498 (2005). }\end{array}$ & $\begin{array}{l}\text { HEU-MET- } \\
\text { MIXED-012 } \\
\text { (Criticality only) }\end{array}$ \\
\hline $\begin{array}{l}\text { Zero Power Physics } \\
\text { Reactor (ZPPR)-20E } \\
\text { (SP-100 Subcritical } \\
\text { Earth Burial Accident) }\end{array}$ & $\begin{array}{l}\text { HEU Metal } \\
\text { BeO Reflected } \\
\mathrm{Nb} / \mathrm{Zr} / \text { Re Clad } \\
\text { Depleted-Li \& Na } \\
\text { Coolant } \\
\text { W/Be/B-Poly Flight } \\
\text { Shield } \\
\mathrm{B}_{4} \mathrm{C} \text { Control Rods }\end{array}$ & $\begin{array}{l}\text { Simulated earth burial } \\
\text { subcriticality using } \\
\text { modified source } \\
\text { multiplication (MSM) } \\
\text { technique }\end{array}$ & $\begin{array}{l}\text { D.N. Olsen, et al., "Experiments for the SP-100 Space } \\
\text { Reactor in ZPPR-20,” INL/EXT-05-00556 \& ANL- } \\
\text { ZPR-497 (2005). } \\
\text { D.N. Olsen, et al., "Configurations for SP-100 } \\
\text { Experiments in ZPPR-20,” INL/EXT-05-00558 \& ANL- } \\
\text { ZPR-498 (2005). }\end{array}$ & $\begin{array}{l}\text { SUB-HEU-MET- } \\
\text { FAST-001 }\end{array}$ \\
\hline
\end{tabular}




\begin{tabular}{|c|c|c|c|c|}
\hline Data Source & Design Basics & Measurements & Documentation & Benchmark \\
\hline $\begin{array}{l}\text { Zero Power Physics } \\
\text { Reactor (ZPPR)-20D } \\
\text { (SP-100 Subcritical } \\
\text { Water Immersion } \\
\text { Accident) }\end{array}$ & $\begin{array}{l}\text { HEU Metal } \\
\text { BeO Reflected } \\
\mathrm{Nb} / \mathrm{Zr} / \mathrm{Re} \text { Clad } \\
\text { Depleted-Li \& } \mathrm{Na} \\
\text { Coolant } \\
\text { W/Be/B-Poly Flight } \\
\text { Shield } \\
\mathrm{B}_{4} \mathrm{C} \text { Control Rods }\end{array}$ & $\begin{array}{l}\text { Simulated water } \\
\text { immersion subcriticality } \\
\text { using modified source } \\
\text { multiplication (MSM) } \\
\text { technique } \\
\text { *Water simulated with } \\
\text { polyethylene }\left(\mathrm{CH}_{2}\right)\end{array}$ & $\begin{array}{l}\text { D.N. Olsen, et al., "Experiments for the SP-100 Space } \\
\text { Reactor in ZPPR-20," INL/EXT-05-00556 \& ANL- } \\
\text { ZPR-497 (2005). } \\
\text { D.N. Olsen, et al., "Configurations for SP-100 } \\
\text { Experiments in ZPPR-20,” INL/EXT-05-00558 \& ANL- } \\
\text { ZPR-498 (2005). }\end{array}$ & $\begin{array}{l}\text { SUB-HEU-MET- } \\
\text { MIXED-001 }\end{array}$ \\
\hline $\begin{array}{l}\text { Zero Power Physics } \\
\text { Reactor (ZPPR)-16A \& } \\
\text { B (SP-100 Early Design } \\
\text { Study) }\end{array}$ & $\begin{array}{l}\text { HEU-N Fuel } \\
\text { (Simulated with UC) } \\
\text { BeO Reflected } \\
\text { Li Coolant } \\
\text { (Simulation with Na) } \\
\text { W/B }{ }_{4} \mathrm{C} / \mathrm{C} \text { Shield } \\
\mathrm{B}_{4} \mathrm{C} \text { Control Rods }\end{array}$ & $\begin{array}{l}\text { Criticality, shim rod } \\
\text { calibrations, gap worth, } \\
\text { shutdown worths, delayed } \\
\text { neutron parameters, } \\
\text { control rod worths, } \\
\text { reflector worths, reaction } \\
\text { rates, reaction rate } \\
\text { distribution, gamma ray } \\
\text { dose, kinetics } \\
\text { measurements, neutron } \\
\text { spectra, material worths }\end{array}$ & $\begin{array}{l}\text { D.N. Olsen, et al., "Configurations and Experiments in } \\
\text { the ZPPR-16 Power Reactor Space Benchmark } \\
\text { Program," INL/EXT-05-00555 \& ANL-ZPR-475 } \\
\text { (2005). }\end{array}$ & NA \\
\hline $\begin{array}{l}\text { Zero Power Physics } \\
\text { Reactor (ZPPR)-C (SP- } \\
100 \text { Early Design Study, } \\
\text { Water Immersion } \\
\text { Scenario) }\end{array}$ & $\begin{array}{l}\text { HEU-N Fuel } \\
\text { (Simulated with UC) } \\
\text { No Reflector } \\
\text { Li Coolant } \\
\text { (Simulation with Na) } \\
\text { W/B }{ }_{4} \mathrm{C} / \mathrm{C} \text { Shield } \\
\mathrm{B}_{4} \mathrm{C} \text { Control Rods }\end{array}$ & $\begin{array}{l}\text { Simulated water } \\
\text { immersion }\end{array}$ & $\begin{array}{l}\text { D.N. Olsen, et al., "Configurations and Experiments in } \\
\text { the ZPPR-16 Power Reactor Space Benchmark } \\
\text { Program," INL/EXT-05-00555 \& ANL-ZPR-475 } \\
\text { (2005). }\end{array}$ & NA \\
\hline $\begin{array}{l}\text { Validation of physics } \\
\text { tools for JIMO reactor } \\
\text { design }\end{array}$ & & & $\begin{array}{l}\text { T. Marcille, "Physics Qualification: JIMO Reactor } \\
\text { Module: Critical Benchmark Experiment Review for } \\
\text { Application to JIMO," LANL-CP-04-0706 (Aug 2004). }\end{array}$ & N/A \\
\hline $\begin{array}{l}\text { Validation of SP-100 } \\
\text { ZPPR tests during } \\
\text { NRPCT / JIMO }\end{array}$ & & & $\begin{array}{l}\text { T. Marcille, "Physics Qualification: JIMO Reactor } \\
\text { Module: ZPPR-16 and ZPPR-20 Qualification Task," } \\
\text { LANL-CP-04-0723 (Sept 2004). }\end{array}$ & \\
\hline
\end{tabular}




\begin{tabular}{|c|c|c|c|c|}
\hline Data Source & Design Basics & Measurements & Documentation & Benchmark \\
\hline $\begin{array}{l}\text { Zero Power Reactor } \\
\text { (ZPR)-9/7, 8, \& } 9 \text { (HEU } \\
\text { Assembly) }\end{array}$ & $\begin{array}{l}\text { HEU Metal Fuel } \\
\mathrm{W} / \mathrm{Al} \text { or } \mathrm{W} / \mathrm{Al}_{2} \mathrm{O}_{3} \\
\text { Plates } \\
\mathrm{Al} \text { Clad } \\
\mathrm{Al}_{2} \mathrm{O}_{3}, \mathrm{Al}, \mathrm{BeO} \\
\text { Reflected }\end{array}$ & $\begin{array}{l}\text { Criticality, kinetic parameters, control rod } \\
\text { calibrations, reaction rates, reaction rate } \\
\text { distributions, material reactivity worths, } \\
\text { control rod worths, reflector worths, gap } \\
\text { worths }\end{array}$ & See Benchmark Report & $\begin{array}{l}\text { HEU-MET-FAST-070 } \\
\text { (Criticality only) }\end{array}$ \\
\hline $\begin{array}{l}\text { Zero Power Reactor } \\
\text { (ZPR)-9/34 (HEU } \\
\text { Assembly) }\end{array}$ & $\begin{array}{l}\text { HEU Metal Fuel } \\
\text { Fe Plates } \\
\text { SS Clad } \\
\text { SS Reflected } \\
\text { DU Shield }\end{array}$ & $\begin{array}{l}\text { Criticality, control rod worths, gap worth, } \\
\text { shield worth, kinetic parameters, neutron } \\
\text { spectra, reaction rates, reaction rate } \\
\text { distributions, material reactivity worths, } \\
\text { Doppler effects }\end{array}$ & See Benchmark Report & $\begin{array}{l}\text { HEU-MET-INTER-001 } \\
\text { (Criticality only) }\end{array}$ \\
\hline
\end{tabular}




\begin{tabular}{|c|c|c|c|c|}
\hline Data Source & Design Basics & Measurements & Documentation & Benchmark \\
\hline SPERT III E-core & $\begin{array}{l}\text { Slightly enriched } \mathrm{UO}_{2} \\
\text { Water-moderated }\end{array}$ & $\begin{array}{l}\text { Transient analysis: step- } \\
\text { reactivity induced power } \\
\text { excursion tests }\end{array}$ & $\begin{array}{l}\text { S.G. Forbes and W.E. Nyer, Dynamic Properties of } \\
\text { Heterogeneous Water Reactors, IDO-16701, July } \\
\text { 1961. (OSTI ID 4841311) }\end{array}$ & NA \\
\hline SPERT IV & $\begin{array}{l}\text { Highly enriched, plate type } \\
\mathrm{UO}_{2} \\
\text { Light water-moderated }\end{array}$ & $\begin{array}{l}\text { Criticality, control rod } \\
\text { worth, void coefficient }\end{array}$ & $\begin{array}{l}\text { J.G. Crocker, et al., Nuclear Start-up of the SPERT- } \\
\text { IV Reactor, IDO-16905, July 1963. (OSTI ID } \\
4647654 \text { ) }\end{array}$ & NA \\
\hline $\begin{array}{l}\text { SPERT I Destructive } \\
\text { Test }\end{array}$ & $\begin{array}{l}\text { Aluminum plate-type core } \\
\text { Water-moderated }\end{array}$ & $\begin{array}{l}\text { Analysis of destructive } \\
\text { mechanisms }\end{array}$ & $\begin{array}{l}\text { R.W. Miller, et al., Report of the SPERT I } \\
\text { Destructive Test Program on an Aluminm, Plate- } \\
\text { Type, Water-Moderated Reactor, IDO-16883, June } \\
\text { 1964. (OSTI ID 4034065) }\end{array}$ & NA \\
\hline $\begin{array}{l}\text { LANL critical } \\
\text { experiment on PLANET } \\
\text { to investigate Re clad } \\
\text { material }\end{array}$ & $\begin{array}{l}\text { HEU Foils } \\
\text { Poly Moderated / Reflected } \\
\text { Re Foils }\end{array}$ & 1 critical configuration & NA & $\begin{array}{l}\text { HEU-MET- } \\
\text { THERM-033 }\end{array}$ \\
\hline $\begin{array}{l}\text { W-Diluted, Be- \& BeO- } \\
\text { Moderated HEU } \\
\text { Cylinder (VNIITF } \\
\text { experiment) }\end{array}$ & $\begin{array}{l}\text { HEU Metal Discs } \\
\text { Tungsten Discs } \\
\text { Be \& BeO Moderated } \\
\text { DU Reflected }\end{array}$ & 1 critical configuration & NA & $\begin{array}{l}\text { HEU-MET- } \\
\text { FAST-052 }\end{array}$ \\
\hline $\begin{array}{l}\text { Be- \& BeO-Moderated } \\
\text { HEU Cylinders } \\
\text { (VNIITF experiment) }\end{array}$ & $\begin{array}{l}\text { HEU Metal Discs } \\
\text { Be \& BeO Moderated } \\
\text { DU Reflected }\end{array}$ & 2 critical configurations & NA & $\begin{array}{l}\text { HEU-MET- } \\
\text { FAST-038 }\end{array}$ \\
\hline $\begin{array}{l}\text { HEU Cylinder with Poly } \\
\text { and W (VNIITF } \\
\text { experiment) }\end{array}$ & $\begin{array}{l}\text { HEU Metal Discs } \\
\text { Tungsten Discs } \\
\text { Poly Moderated } \\
\text { Poly Reflected }\end{array}$ & 1 critical configuration & NA & $\begin{array}{l}\text { HEU-MET- } \\
\text { MIXED-017 }\end{array}$ \\
\hline $\begin{array}{l}\text { SNL Annular Core } \\
\text { Research Reactor } \\
\text { (ACRR) }\end{array}$ & $\begin{array}{l}\mathrm{UO}_{2} \text {-BeO Fuel } \\
\mathrm{SS} \text { Clad } \\
\text { Water Moderated } \\
\text { Water Reflected } \\
\mathrm{U}-\mathrm{ZrH} \text { fuel in Fuel-Ringed } \\
\text { External Cavities (FREC) } \\
\mathrm{B}_{4} \mathrm{C} \text { Control Rods }\end{array}$ & Details unknown & $\begin{array}{l}\text { K. R. DePriest, et al., "MCNP/MCNPX Model of } \\
\text { the Annular Core Research Reactor," SAND2006- } \\
3067 \text { (2006). }\end{array}$ & NA \\
\hline
\end{tabular}




\begin{tabular}{|c|c|c|c|c|}
\hline Data Source & Design Basics & Measurements & Documentation & Benchmark \\
\hline $\begin{array}{l}\text { Small Be-Reflected } \mathrm{UO}_{2} \\
\text { Critical Assembly }\end{array}$ & $\begin{array}{l}\mathrm{HEU}-\mathrm{O}_{2} \text { Fuel } \\
\text { Be Reflected } \\
\text { SS347 Clad }\end{array}$ & $\begin{array}{l}\text { Criticality, fuel displacement, } \\
\text { radial and axial fission rates, } \\
\text { cadmium ratios, reflector } \\
\text { thickness, sample material } \\
\text { worths, potassium coolant } \\
\text { worth }\end{array}$ & $\begin{array}{l}\text { J.T. Mihalczo, “A Small } \\
\text { Beryllium-Reflected UO } \\
\text { Assembly,” ORNL-TM-655 } \\
\text { (1963). }\end{array}$ & $\begin{array}{l}\text { Tentatively Scheduled for } \\
\text { Completion in FY13 }\end{array}$ \\
\hline $\begin{array}{l}\text { Be and Mo reflected } \\
\text { cylinders of HEU }\end{array}$ & $\begin{array}{l}\text { Fuel: } 96.5 \mathrm{wt} \%{ }^{235} \mathrm{U}-\mathrm{Mo} \text { alloy } \\
\text { Case } 1: \text { Mo-ref assembly } \\
\text { Case } 2: 2 \text { rows Be ref tubes } \\
\text { surrounding core } \\
\text { Case } 3: 4 \text { row Be ref tubes } \\
\text { Case } 4: \text { Be lateral reflector } \\
\text { Case } 5: 1 \text { row Mo ref tubes, } \\
\text { other ref tubes w/Be pellets } \\
\text { Case } 6: 2 \text { rows Mo ref tubes }\end{array}$ & Criticality & See benchmark & $\begin{array}{l}\text { HEU-MET-FAST-005 } \\
\text { Criticality only }\end{array}$ \\
\hline Bare sphere of HEU & $\sim 90 \mathrm{wt} \% \mathrm{U}-235$ & Criticality & See benchmark & $\begin{array}{l}\text { HEU-MET-FAST-008 } \\
\text { Criticality only }\end{array}$ \\
\hline $\begin{array}{l}\text { HEU spheres reflected by Be } \\
\text { or } \mathrm{BeO}\end{array}$ & $\begin{array}{l}\sim 90 \mathrm{wt} \% \mathrm{U}-235 \\
\mathrm{Be}, \mathrm{BeO}\end{array}$ & Criticality & See benchmark & $\begin{array}{l}\text { HEU-MET-FAST-009 } \\
\text { Criticality only }\end{array}$ \\
\hline $\begin{array}{l}\text { HEU spheres reflected by } \mathrm{B}+ \\
\mathrm{Be} \text { or } \mathrm{B}+\mathrm{BeO}\end{array}$ & $\begin{array}{l}\text { } 90 \text { wt } \% \text { U- } 235 \\
\text { B: } 74.68 \text { wt. } \% \text { natB and } \\
25.32 \text { wt. } \% \mathrm{CH} \\
\text { Be: } 0.490 \pm 0.05 \text { wt. } \% \\
\text { impurities: } 0.11 \pm 0.02 \text { wt. } \% \\
\text { C, } 0.12 \pm 0.02 \text { wt. } \% \text { O, and } \\
0.26 \pm 0.03 \text { wt. } \% \mathrm{Fe} \\
\text { BeO: } 0.14 \pm 0.03 \text { wt. } \% \\
\text { impurities ( } 0.03 \pm 0.01 \text { wt. } \% \text { C } \\
\text { and } 0.11 \pm 0.03 \text { wt. } \% \mathrm{Fe})\end{array}$ & Criticality & See benchmark & $\begin{array}{l}\text { HEU-MET-FAST-010 } \\
\text { Criticality only }\end{array}$ \\
\hline $\begin{array}{l}\text { HEU spheres reflected by } \\
\text { polyethylene }\end{array}$ & & Criticality & See benchmark & HEU-MET-FAST-011 \\
\hline $\begin{array}{l}\text { HEU spheres reflected by } \\
\text { steel }\end{array}$ & $\begin{array}{l}\sim 90 \mathrm{wt} \% \text { U-235 } \\
\text { steel shells: St.20 steel --Fe }\end{array}$ & Criticality & See benchmark & $\begin{array}{l}\text { HEU-MET-FAST-013 } \\
\text { Criticality only }\end{array}$ \\
\hline
\end{tabular}




\begin{tabular}{|c|c|c|c|c|}
\hline Data Source & Design Basics & Measurements & Documentation & Benchmark \\
\hline & $\begin{array}{l}\text { containing } 0.17-0.23 \text { wt. } \% \mathrm{C} \text {, } \\
0.12-0.30 \text { wt. } \% \\
\mathrm{Si}, 0.4-0.65 \text { wt. } \% \mathrm{Mn} \text {, and } \\
<0.15 \text { wt. } \% \mathrm{Cr}\end{array}$ & & & \\
\hline $\begin{array}{l}\text { HEU cylinders reflected by } \\
\mathrm{Be} \text { or } \mathrm{BeO}\end{array}$ & $\begin{array}{l}96 \mathrm{wt} \% \mathrm{U}-235 \\
\mathrm{Be} \text { or BeO end reflectors } \\
\mathrm{Be}: 98.49 \mathrm{wt} \% \mathrm{Be}, 1.51 \mathrm{wt} \% \mathrm{O}\end{array}$ & Criticality & See benchmark & $\begin{array}{l}\text { HEU-MET-FAST-016 } \\
\text { Criticality only }\end{array}$ \\
\hline $\begin{array}{l}\text { HEU cylinders moderated } \\
\text { and reflected by Be }\end{array}$ & $\begin{array}{l}96 \mathrm{wt} \% \mathrm{U}-235 \\
\text { Be:98.49wt } \% \text { Be, } 1.51 \mathrm{wt} \% \mathrm{O}\end{array}$ & Criticality & See benchmark & $\begin{array}{l}\text { HEU-MET-FAST-017 } \\
\text { Criticality only }\end{array}$ \\
\hline $\begin{array}{l}\text { Polyethylene spherical } \\
\text { assembly of } 90 \% \text { U-235 }\end{array}$ & $\begin{array}{l}\text { 90wt\% U-235 } \\
\text { Polyethylene }\end{array}$ & Criticality & See benchmark & HEU-MET-FAST-020 \\
\hline $\begin{array}{l}\text { Sphere of HEU, reflected by } \\
\text { steel and polyethylene }\end{array}$ & & Criticality & See benchmark & HEU-MET-FAST-024 \\
\hline $\begin{array}{l}\text { Heterogeneous cylinder of } \\
\text { HEU w/Be moderator and } \\
\text { DU reflector }\end{array}$ & & Criticality & See benchmark & HEU-MET-FAST-030 \\
\hline $\begin{array}{l}\text { Heterogeneous cylinder of } \\
\mathrm{HEU} \text { w/Be and } \mathrm{BeO} \\
\text { moderators and } \mathrm{DU} \text { reflector }\end{array}$ & $\begin{array}{l}\text { HEU Metal Discs } \\
\text { Be \& BeO Moderated } \\
\text { DU Reflected }\end{array}$ & 2 critical configurations & See benchmark & HEU-MET-FAST-038 \\
\hline $\begin{array}{l}\text { HEU sphere, Be reflector } \\
(1950 \mathrm{~s}) \\
\text { Comet assembly machine }\end{array}$ & $\begin{array}{l}\text { Two Be-reflected } \\
\text { configurations ( } 1.85 \text {-in, } 4.64 \text { - } \\
\text { in thick reflector) } \\
{ }^{235} \mathrm{U}, 93.5 \mathrm{wt} . \%, 18.8 \mathrm{~g} / \mathrm{cm}^{3} \text {, } \\
\text { in hemispherical shells }\end{array}$ & $\begin{array}{l}\text { Subcritical; measurements } \\
\text { used to extrapolate to critical } \\
\text { mass ( } 1 / \mathrm{M} \text { method) with } \\
\text { decreasing separation distance }\end{array}$ & See benchmark & HEU-MET-FAST-041 \\
\hline $\begin{array}{l}\text { "Nimbus" experiment series } \\
\text { Nimbus assembly machine }\end{array}$ & $\begin{array}{l}\text { Close-fitting nested HEU } \\
\text { metal hemispherical shells } \\
93.17 \text { wt. } \%{ }^{235} \mathrm{U}, 18.6 \mathrm{~g} / \mathrm{cm}^{3} \\
\text { Central cavity filled with Be }\end{array}$ & $\begin{array}{l}\text { Criticality, } 5 \text { configurations } \\
\text { Measurements used to } \\
\text { extrapolate to critical mass } \\
\text { (1/M method) with increasing }\end{array}$ & See benchmark & HEU-MET-FAST-058 \\
\hline
\end{tabular}




\begin{tabular}{|c|c|c|c|c|}
\hline Data Source & Design Basics & Measurements & Documentation & Benchmark \\
\hline & $\begin{array}{l}\text { metal shells; additional Be } \\
\text { metal shells as outer reflector } \\
\text { Be: } 1.84 \mathrm{~g} / \mathrm{cm}^{3} \pm 2.5 \% \text {, up to } \\
2 \text { wt. } \% \mathrm{BeO}\end{array}$ & $\begin{array}{l}\text { Be thickness }(0.875 \text {-in. to } \\
7.98 \text {-in. Be for } 32.7 \mathrm{~kg} \text { to } 108 \\
\text { kg HEU, respectively) }\end{array}$ & & \\
\hline $\begin{array}{l}\text { "Nimbus" experiment series } \\
\text { continued }\end{array}$ & $\begin{array}{l}\text { Close-fitting nested HEU } \\
\text { metal hemispherical shells } \\
93.17 \text { wt. } \%{ }^{235} \mathrm{U}, 18.6 \mathrm{~g} / \mathrm{cm}^{3} \\
\text { Central cavity filled with Be } \\
\text { metal shells; additional Be } \\
\text { metal shells as outer reflector }\end{array}$ & $\begin{array}{l}\text { Criticality, } 9 \text { configurations } \\
\text { Additional HEU mass and Be } \\
\text { thickness combinations tested }\end{array}$ & See benchmark & HEU-MET-FAST-066 \\
\hline $\begin{array}{l}\text { "Nimbus" experiment series } \\
\text { continued }\end{array}$ & $\begin{array}{l}\text { Close-fitting nested HEU } \\
\text { metal hemispherical shells } \\
93.17 \text { wt. } \%{ }^{235} \mathrm{U}, 18.6 \mathrm{~g} / \mathrm{cm}^{3} \\
\text { Central cavity filled with Be } \\
\text { metal shells; additional Be } \\
\text { metal shells as outer reflector }\end{array}$ & & See benchmark & $\begin{array}{l}\text { HEU-MET-FAST-077 } \\
\text { To be published }\end{array}$ \\
\hline $\begin{array}{l}\text { Oak Ridge Critical } \\
\text { Experiments Facility, } \\
\text { Be-metal-reflected HEU }\end{array}$ & $\begin{array}{l}>93 \%{ }^{235} \mathrm{U} \\
\text { Be-metal reflected }\end{array}$ & & See benchmark & HEU-MET-FAST-059 \\
\hline $\begin{array}{l}\text { Oak Ridge Critical } \\
\text { Experiments Facility, } \\
\text { Be-metal-reflected HEU }\end{array}$ & $\begin{array}{l}>93 \%{ }^{235} \mathrm{U} \\
\text { Be-metal reflected }\end{array}$ & & See benchmark & HEU-MET-FAST-069 \\
\hline
\end{tabular}




\section{Recent Analyses of Testing Needs for Small Space Reactor Systems}

Several studies have been conducted in recent years to assess the need for reactor physics and criticality testing to support the development of a qualified space reactor system, taking into account previous experimental programs and similarity in materials and design between the tested configurations and the current reactor design under consideration. Recent studies supported the reactor design task during the Jupiter Icy Moons Orbiter (JIMO) program (cancelled in 2005) and the fission surface power program. This section summarizes these recent studies and their associated conclusions.

\section{III.A. JIMO Reactor Studies: Comparison to SP-100 Validation Experiments}

The JIMO reactor concept differed in power level and lifetime from the baseline FSP design, leading to consideration of different fuels, materials, and operating temperature than the FSP reactor. Although the conceptual JIMO reactor design was not finalized by the time the program was terminated, the design focused on the use of highly enriched fuel and refractory metal clad and structural materials. Pumped liquid metal-cooled, gas-cooled and heat pipe-cooled designs were considered in the design process. All proposed JIMO reactor concepts used enriched ${ }^{235} \mathrm{U}$ as the fissionable fuel material, and none had an enrichment of less than $19.9 \mathrm{wt} \%$. Most incorporated uranium nitride (UN) or uranium dioxide $\left(\mathrm{UO}_{2}\right)$ fuel types. Hence, a study performed by Marcille at LANL [2004a] to determine applicable ICSBEP benchmarks considered only those having intermediate and highly enriched uranium (IEU, 10-60 wt\%

${ }^{235} \mathrm{U}$, and $\mathrm{HEU},>60 \mathrm{wt} \%{ }^{235} \mathrm{U}$ ) fuel and did not consider experiments fueled with plutonium, mixed plutonium-uranium, or low enriched uranium (LEU) for applicability to JIMO. Marcille [2004b] concluded that the JIMO space reactor conceptual design space was highly similar to the SP-100 configurations tested in the ZPPR-20C, D, and E experiments. At the time of the study, these ZPPR configurations were in the process of being benchmarked by the ICSBEP. Those benchmarks are now complete and are available to the FSP program. Note that the Naval Reactors Primary Contractor Team (NRPCT) selected a highly enriched $\mathrm{UO}_{2}$ fueled, gas-cooled design as the reference design just prior to the cancellation of the JIMO project in September 2005 [NRPCT 2006]; however, this down-select was made after Marcille issued his 2004 reports on applicability of the ZPPR tests conducted for the SP-100 reactor program.

\section{Details on the SP-100 Criticality Test Series: ZPPR-16 and -20}

Two series of critical tests were performed in support of SP-100: ZPPR-16 and -20. The ZPPR-16 assemblies were a simple mockup of the $300 \mathrm{kWe}$ SP-100 reactor and were conducted early in the development of that reactor design. The experiments incorporated enriched uranium metal fuel $(37 \%<$ $\mathrm{HEU}<93 \%$ ), sodium coolant, $\mathrm{B}_{4} \mathrm{C}$ internal safety rods and $\mathrm{BeO}$ external radial reflectors. Three separate assemblies were tested to assess the effects of the safety rods, radial reflector, varying fuel enrichment zones, and a flooded reactor accident scenario. Measurements and calculations included eigenvalues, control system worths, and power distributions.

The ZPPR-20 assembly was a detailed, complex mockup of the 100-kWe SP-100 space reactor design. The measurements perfomed in the ZPPR-20 engineering mock-up critical validated the principal physics parameters of the SP-100 reactor design. The reactor design evolution included many more material and 
design features not included in the previous ZPPR-16 campaign, such that the ZPPR-20 series of experiments was deemed more applicable to the JIMO reactor qualification. The ZPPR-20 assembly included rhenium, zirconium alloy, hafnium, high-purity ${ }^{7} \mathrm{Li}$, and lithium hydride. Several comprehensive reports comparing the measured versus calculated system parameters were produced by GE and Westinghouse in support of the ZPPR-20 test series, and sufficient information on the test configurations was available for experiment benchmarking [Porter, Andre and Doncals 1990; Olsen et al. 2005a, 2005b]. Phases C, D, and E of the ZPPR-20 test series were specific to the reference flight system, such that no facility shield or ex-reactor pressure vessel configuration was included in the assemblies. These configurations included the following:

- Phase C: Simulation of reference flight system.

- Phase D: Simulation of several water immersion accidents (all void and coolant spaces replaced with polyethylene and $\mathrm{CH}_{2}$ ).

- Phase E: Simulation of earth burial accident (core surrounded with 8 inches $\mathrm{SiO}_{2}$ and 7 inches $\mathrm{Na}_{2} \mathrm{CO}_{3}$ ).

Measurements included eigenvalue determination, measurement of control and reflector worth, and power distributions.

Original calculations performed during the SP-100 project for the ZPPR-20 configurations used the ENDF/B-V.2 cross section evaluations with $\operatorname{MCNP}(3 \mathrm{~A})$. These calculations indicated deficiencies in the cross section evaluations that would have a significant impact on eigenvalue predictions. The ZPPR-20 eigenvalues were over-predicted by more than one percent, control rod worths were approximately $15 \%$ low, and $\mathrm{BeO}$ reflector worth was consistently under-predicted.

Marcille [2004b] found that re-computing the eigenvalues for the ZPPR-20 configurations using MCNP/MCNPX with ENDF/B-VI cross section data sets, which was the most up-to-date evaluation at that time, yielded significantly reduced eigenvalue biases. Marcille's report concludes with the recommended path forward:

- Completely reanalyze ZPPR-20C, 20D, and 20E eigenvalue, control drum worth and power distribution calculations using new simulation models in MCNPX with updated cross section evaluations.

- Analysis should focus on sensitivities to $\mathrm{BeO}, \mathrm{B}$, and Fe cross sections:

i. Significant eigenvalue differences were noted for SS-reflected fast spectrum systems; consider direct-difference eigenvalue calculations using ENDF/B-V and ENDF/B-VI iron in stainless steel.

ii. ENDF cross section evaluations are currently considered as the baseline modeling tool for FSP (as it was for JIMO); Marcille recommended consideration of JEF and JENDL libraries, specifically for iron, to assess the potential effect on eigenvalue uncertainty.

iii. Application of modified $\mathrm{Be}$ elastic cross-section data to the $\mathrm{BeO}$ reflector worth calculation cases to determine eigenvalue sensitivity, given unreasonable radial reflector worth predictions from ZPPR-20B and $\mathrm{C}$ assemblies (Be cross section data will be discussed in section IV.A; recent updates to Be evaluations may impact the overall FSP uncertainty, but they are not yet available for inclusion in the models). 
The JIMO reactor qualification task included an additional sub-task to perform specific re-calculations of the modeled ZPPR configurations using updated material and geometry models and then-current ENDF/B-VI cross section data to assess potential improvements in previously determined systematic eigenvalue bias, control worth, spatial power and reaction rate distribution predictions. Additional simulations would then have been performed to establish eigenvalue and worth biases for JIMO reactor design. The JIMO program was terminated before this task was completed (September 2005).

The as-built configurations for ZPPR-20C, D, and E have been obtained from the corresponding benchmark evaluations and have been updated to use to most recent ENDF cross section evaluations (ENDF/B-VII.0). The critical eigenvalue calculation for the 20C (loading 105), 20D (loadings 129, 136) and 20E (loading 160) configurations were repeated using MCNP5 1.51 and the ENDF/B-VII.0 evaluations with the updated thermal scattering $(S(\alpha, \beta))$ data, where available. Parry et al. [2008] report the bias in the calculated result, where bias is defined as the difference in the calculated $\mathrm{k}_{\text {eff, }} \mathrm{k}_{\text {calculated, }}$, and the benchmark $\mathrm{k}_{\text {eff, }} \mathrm{k}_{\text {benchmark: }}$ :

$$
\begin{gathered}
\text { bias }=k_{\text {calculated }}-k_{\text {benchmark }}, \text { or } \\
\% \text { bias }=\frac{k_{\text {calculated }}-k_{\text {benchmark }} \% .}{k_{\text {b }}} .
\end{gathered}
$$

The reported $k_{\text {benchmark }}$ corrects the measured $k_{\text {eff }}, k_{\text {experimental }}$, for known biases in the experimental configuration:

$$
k_{\text {benchmark }}=k_{\text {experimental }}-\Delta k_{\text {materials,geometry, room return,etc. }} .
$$

Calculations were repeated for the as-built models for the four experiments noted. Note that the bias calculations included in Parry et al. were in error for the $20 \mathrm{C}$ results (hmf075), as they were calculated as a bias between the experimental $\mathrm{k}_{\mathrm{eff}}$ of 1.0 rather than the corrected benchmark $\mathrm{k}_{\mathrm{eff}}$ of 0.9985 ; the bias reported in Table 6 was re-calculated using the above expressions.

Table 6. Experimental measurement and calculated $\mathrm{k}_{\mathrm{eff}}$ for the indicated SP-100 test series. The benchmark and MCNP5 1.40 results were included in Parry et al. [2008]; the MCNP5 1.51 results were calculated for the current

\begin{tabular}{|c|c|c|c|c|c|c|c|c|}
\hline & \multirow[b]{2}{*}{$\mathrm{k}_{\text {eff }}$} & \multirow[b]{2}{*}{ error } & \multicolumn{3}{|c|}{ ENDF/B-VII } & \multicolumn{3}{|c|}{ ENDF/B-VII } \\
\hline & & & $\mathrm{k}_{\mathrm{eff}}$ & error & bias & $\mathrm{k}_{\mathrm{eff}}$ & error & bias \\
\hline ZPPR20C & 00005 & 7רחת & 101400 & 000026 & 0.01559 & 101256 & 2 $200 \Omega$ & 0.01506 \\
\hline (loading 105) & (2. & U. 00 - & $1.0+403$ & $\theta .0 \cos \theta$ & $(0.16 \%)$ & 1.04330 & 0.00033 & $(1.5 \%)$ \\
\hline ZPPR20D & 10047 & 0 & 100632 & $0 \Omega 8$ & 0.00213 & 657 & 0 & 0.00237 \\
\hline (loading 129) & $1.004 z$ & 0.0024 & 1.00035 & $0 . \forall$ & $(0.21 \%)$ & 1.0003 & 0. & $(0.23 \%)$ \\
\hline ZPPR20D & 00585 & 00038 & 00 & & 0.00687 & & 00 & 0.00695 \\
\hline (loading 136) & (4.2803 & 4.0030 & U.9 & U. & $(0.69 \%)$ & U. & U.0 & $(0.69 \%)$ \\
\hline ZPPR20E & 00127 & 00075 & 003650 & 000031 & 0.02389 & 003513 & 000021 & 0.02243 \\
\hline (loading 160) & & & 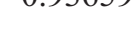 & U. & $(2.4 \%)$ & 0.8 & U. & $(2.2 \%)$ \\
\hline
\end{tabular}
project. Note that all calculation results correspond to the as-built MCNP models.

$\begin{array}{llll}\text { Case } & \text { Benchmark } & \text { MCNP5 1.40 } & \text { MCNP5 1.51 }\end{array}$

The reflector worth for the ZPPR20C experiment was also calculated via direct difference calculation. Replacement of all beryllium in the MCNP input deck with void resulted in a drop in the $\mathrm{k}_{\text {eff }}$ to $0.80814 \pm$ 0.00040 , indicating beryllium worth in this configuration of approximately $20 \%$ of the total worth. This calculation was performed using MCNP5 1.51 with ENDF/B-VII.0. 


\section{III.B. Fission Surface Power System Studies}

In 2007 INL performed a study to determine which, if any, of the existing benchmarked datasets included in the ICSBEP were applicable to an FSP-class reactor design and to assess the applicability of existing, operational criticality test facilities, both domestic and international, to potential physics and qualification testing for space power reactors [Weaver 2007]. The "baseline" design considered in 2007 does not differ significantly from the current FSP model.

At the time of the 2007 study several critical test facilities were available, both domestically and internationally (Japan, France, Switzerland, and Russia). Foreign facilities will not be addressed in the current report, as it is not expected that these will be considered for near-term reactor physics and qualification testing by NASA and DOE. Two domestic facilities were available (or were being prepared for use) in 2007: the Device Assembly Facility (DAF), which contains the Critical Experiments Facility (CEF), located at the Nevada Test Site (NTS), and the ZPPR facility at the Idaho National Laboratory. Since that time, the ZPPR facility has been decommissioned and is no longer available for criticality testing. Hence, discussion on the path forward for nuclear testing in this report (section IV) will only address experiments conducted at the DAF CEF; additional non-critical experiments could be conducted at various laboratories around the country, as will be discussed in section IV.

Weaver reviewed experiment sets in both the International Reactor Physics Evaluation Project (IRPhEP) and the ICSBEP. None of the sets included in the IRPhEP database were found to be applicable to an FSP-class reactor, but 14 experiments included in the ICSBEP database were found to be potentially applicable. Weaver focused on simple configurations of HEU, fast spectrum systems in either bare or reflected configurations using Be or steel. As noted in the earlier study by Marcille [2004] for the JIMO reactor, Weaver found ZPPR-16 and -20 to be highly applicable to the FSP design. Benchmarks identified by Weaver as potentially applicable to the current FSP design are included in Table 5.

A 2008 study conducted by researchers from INL, ORNL and SNL again assessed the need for a zero power critical experiments testing campaign as a component in the qualification of an FSP system [Parry et al. 2008]. Their analysis considered a baseline FSP design incorporating the same materials as applicable to the current model: NaK-cooled, fast spectrum, $93 \%{ }^{235} \mathrm{U}$ enriched $\mathrm{HEU}-\mathrm{O}_{2}$ fuel, SS316 cladding, Be reflector, and $\mathrm{B}_{4} \mathrm{C}$ control drums.

Key conclusions and recommendations offered in the study focused on applicability of previous experimental measurements, namely the ZPPR-20 series of experiments, and potential gaps in the existing database. The study authors recommended that a more comprehensive analysis of ZPPR-20C benchmark model (HEU-MET-FAST-075) might provide sufficient information to confirm the computational model of the FSP and thus eliminate the need for a cold critical experiment. However, they concluded that a cold critical test of the full FSP core could be used to confirm Be-reflector worth and to quantify edge effects between the fueled region (U) and the reflector (Be) if the ZPPR-20C analysis proves insufficient. As noted in the introduction to this report, LANL is currently conducting a computational analysis to determine the sensitivity of the current FSP design to various uncertainties in the material cross sections (total and reaction specific cross sections). Results of the LANL study will be used to determine the need for additional reduction in the cross section uncertainties or FSP for criticality testing. 
Critical experiments show an average bias of less than $0.6 \%$ using the ENDF/B-VII cross-section libraries, while sub-critical experiments show a much larger bias of $1.3-1.7 \%$ in all of the benchmarks analyzed by Parry, et al. [2008]. This bias was noted to increase with increasing reflector worth of the beryllium. Hence, a very high reflector worth system, such as the FSP, is expected to have a larger bias associated, especially for sub-critical experiments. Parry, et al. suggest that analysis of sub-critical experiments may require analytical tools outside of the baseline tool selection (MCNP5 with ENDF/BVII cross section evaluations) to more accurately predict system performance. Additional tools have not been applied to the benchmarked data sets at this time.

Currently, the 2008 study by Parry, et al. indicates that the largest uncertainties associated with the FSP design relate to knowledge of the ${ }^{235} \mathrm{U}(\mathrm{n}, \gamma)$ cross section (covariance uncertainty $2.09 \%$ ) and the ${ }^{9} \mathrm{Be}(\mathrm{n}, \mathrm{n})$ cross section. Covariance data, or uncertainty information, included with cross section data allows for the propagation of cross section data uncertainties via sensitivity studies to the final parameters of interest in a nuclear system. The covariance data files also provide estimates of not just individual data but correlated effects, if they exist, for different materials and reactions [Dunn 2000].

Additional analysis of the ZPPR-20 experiments using MCNP5 1.51 and ENDF/B-VII cross section evaluations was performed by Parry, et al. [2008] for criticality, but not for physics measurements (ZPPR20C, loading 105; ZPPR-20D, loading 129 and 136; ZPPR-20E, loading 160). A penalty assessment was performed to determine the degree to which the FSP model could not be characterized by the ZPPR-20 data. In this manner, the uncertainty in the covariance data was reduced to $0.29 \%$, where $0.28 \%$ of that is due to the uncertainty in the ${ }^{9} \mathrm{Be}$ cross section. The domination of the uncertainty in the covariance data by Be cross sections indicates that Be was not covered sufficiently by these benchmarks. The authors recommended additional cross section measurements to further reduce uncertainty in the ${ }^{9} \mathrm{Be}(\mathrm{n}, \mathrm{n})$ cross section if the overall uncertainty in the FSP model is to be further reduced. Even if the re-analysis of the ZPPR-20 data sets with current modeling tools (e.g. updated MCNP5 release 1.60 and ENDF/B-VII.1 evaluations) suggests that a cold critical experiment is not necessary, a worst-case postulated accident criticality analysis will likely still be needed to validate computational modeling capabilities and to qualify the FSP design given submersion in an additional reflecting and/or moderating medium.

A follow-up to the 2008 study by Parry et al. was performed in an attempt to further reduce the uncertainty due to Be cross section data using three additional Be-reflected, HEU-metal benchmark experiments [Bess, Bledsoe and Reardon 2011]. The ensuing analysis indicated that these benchmarks also did not sufficiently cover the ${ }^{9} \mathrm{Be}(\mathrm{n}, \mathrm{n})$ reaction. The authors found much smaller sensitivity in the selected benchmarks to the Be reactions versus that of the FSP design; hence, they cannot be used to validate the FSP sensitivity to the ${ }^{9} \mathrm{Be}(\mathrm{n}, \mathrm{n})$ reaction.

Using all seven benchmarks identified in the 2008 and 2011 studies, the overall uncertainty of the FSP model was calculated to be $2.02 \%$, while the uncertainty in the covariance data remained at $0.29 \% \delta \mathrm{k} / \mathrm{k}$, with $0.28 \% \delta \mathrm{k} / \mathrm{k}$ resulting from the ${ }^{9} \mathrm{Be}(\mathrm{n}, \mathrm{n})$ reaction. It may be possible to further reduce uncertainties by including additional benchmark experiments with beryllium that incorporate different fuel types [Bess, Bledsoe, Rearden 2011]. For instance, the 1963 experiment conducted at the Oak Ridge Critical Experiments Facility (ORCEF) for a small, compact, unmoderated critical assembly test conducted using HEU-O $\mathrm{O}_{2}$ and reflected by beryllium, noted in Table 5, was developed for space reactor design analysis 
[Mihalczo 1963]. Benchmarking this experiment (slated for 2013) and inclusion of the results in the FSP model may be beneficial in reducing FSP uncertainty. Overall, the series of analyses determined that to further reduce the covariance data uncertainty, benchmark experiments are needed with sensitivities to the ${ }^{9} \mathrm{Be}(\mathrm{n}, \mathrm{n})$ cross sections equivalent to the FSP model [Bess, Bledsoe, Rearden 2011].

\section{Current Test Options}

Reactor physics and qualification testing can include a variety of stages, beginning with "separate effects testing" to ascertain parameters corresponding to individual materials, subcritical testing, and critical testing of simple configurations or more detailed configurations that more closely resemble a full reactor core and reflector design.

\section{IV.A. Separate Effects Testing: Cross Section Measurement and Evaluation}

The largest contributors to the uncertainty in the FSP design have been attributed to the uncertainties associated with individual interaction cross sections for ${ }^{235} \mathrm{U}$ and ${ }^{9} \mathrm{Be}$. While the total cross section for a specific element may be fairly well known, cross sections for specific interactions may have significantly

larger error bars. Interactions of interest for additional cross section measurement might include ${ }^{235} \mathrm{U}(\mathrm{n}, \gamma)$ and various neutron interactions in ${ }^{9} \mathrm{Be}($ e.g. $(n, n),(n, 2 n),(n, \alpha))$ in either Be metal or $\mathrm{BeO}$, along with the associated covariance data.

An initial literature review points to recent use of an accelerator-driven pulsed neutron source and timeof-flight measurement techniques [Danon et al. 2009] for total cross section measurement in ${ }^{9} \mathrm{Be}$ and graphite, and these data are being incorporated in ongoing updates to the cross section evaluations for ${ }^{9} \mathrm{Be}$ [Hale 2011]. Useful separate effects measurements would require knowledge of the neutron energy spectrum of interest to the class of reactor being designed (e.g. small, fast spectrum reactor), the operating temperatures for the material of interest, and the required instrumentation suite to obtain the desired measurement accuracy.

\section{Beryllium Cross Section Data: Recent and Ongoing Evaluations}

The National Nuclear Data Center (NNDC) at Brookhaven National Laboratory collects, evaluates, and disseminates nuclear physics data. Updates to the ${ }^{9} \mathrm{Be}$ cross sections included in the beta 3 version of the ENDF/B-VII.1 library, scheduled to be released in December 2011, will include updates to the total, integrated elastic, and capture cross sections. The preliminary file is currently available at https://ndclx4.bnl.gov/gf/project/endf/scmsvn/?action=browse \&path= $\% 2$ Ftrunk $\% 2$ Fendf $7 \% 2$ Fneutrons $\%$ 2Fn-004 Be 009.endf\&revision=301\&view=markup.

Analysis of the $\mathrm{n}+{ }^{9} \mathrm{Be}$ system that will eventually result in new cross sections for all the reactions, including new elastic scattering angular distributions, is currently being conducted but will not be ready in time for the ENDF/B VII.1 release. The analysis is expected to be complete by the end of FY11, but it will take a longer to assemble and test the files in ENDF format. All evaluations must now include covariance data in addition to the basic cross section information. At the time of writing, the final uncertainties in the resulting cross sections are unknown. Per personal communication, Hale indicates that the current ENDF evaluation is a fairly good representation of the experimental data. However, local 
deviations in the $(n, n),(n, 2 n)$ and $(n, \alpha)$ cross sections could be as much as $10 \%$ in the new evaluations because the existing evaluation tends to smooth out structure in these cross sections. The R-matrix treatment used in the new evaluation will add structure coming from the known resonances. For example, this deviation may be noted in the $(n, \alpha)$ cross section around the peak near $3 \mathrm{MeV}$, and in the (n,2n) cross section in the 3-7 MeV region. Differences are also expected in the manner in which the $(n, 2 n)$ and $(n, \alpha)$ cross sections come up from threshold because theory gives a somewhat different energy dependence there, which is not very well determined by current measurements. Danon et al. [2009] have recently used an iron filtered, pulsed neutron beam method to measure beryllium total cross section to $\sim 1 \%$ accuracy. Hale suggests that this type of data may be useful in further defining the dynamic structure factor for Be, which is related to the thermal scattering treatment, $S(\alpha, \beta)$, but it is currently unclear as to how that data may be used in the evaluations.

The final uncertainties and covariances in the updated evaluations are very difficult to predict at this stage, as this is performed as the last step of the analysis and they depend significantly on the curvature of the chi-square surface in the region of the local minimum (solution) found [Hale 2011]. The output uncertainties typically are considerably smaller than the input experimental errors because of the statistical redundancy of having included a large number of data points to determine a relatively small number of parameters, and the theoretical constraints imposed by the analysis. Most of the measured data that are currently used in the Be cross section evaluations have uncertainties in the 10-15\% range, with the exception of the total cross section. Reduction of these uncertainties to $\sim 3-5 \%$ would provide significantly more information about the resonance structure, which is currently hidden for the most part by the size of the error bars.

Useful new measurements for ${ }^{9} \mathrm{Be}$ might include elastic scattering cross sections over more of the resonances above $500 \mathrm{keV}$, and better measurements of the $(n, 2 \mathrm{n})$ and $(\mathrm{n}, \alpha)$ cross sections at energies above 4-5 MeV. Earlier measurement of the $(n, \alpha)$ cross section, performed by Stelson and Campbell [1957], appear to be reasonable below that energy. At present, there are no new measurements planned for $n+{ }^{9} \mathrm{Be}$. The last known measurements were done at Rensselaer Polytechnic Institute (RPI), and the cross section evaluations have been using the total cross sections measured by Danon et al. (2009) at the iron-filter energies below about $1 \mathrm{MeV}$. It is believed that RPI also performed some differential cross section measurement, but this data has not yet been provided for inclusion in the ${ }^{9} \mathrm{Be}$ evaluations.

Separate effects testing, such as cross section measurement, could be performed at a variety of laboratories, both at DOE national laboratories and at universities. As noted above, recent cross section measurements have been performed at the RPI accelerator facility. Similar measurements could be performed at the Idaho State University Accelerator Center with direct involvement and oversight by the Idaho National Laboratory. Various other facilities around the country would also have capability of measuring cross sections using accelerator-driven systems. What remains to be defined is the diagnostic equipment required to achieve the desired measurement accuracy of 3-5\% for the individual cross sections noted. Facility requirements for cross section measurement will be further clarified in follow-on activities. 


\section{IV.B. Sub-Critical and Critical Testing}

As noted in previous studies, it is expected that sub-critical and critical testing will be required for postulated accident scenarios (e.g. water immersion or wet sand burial) even if cold critical testing of the nominal reactor design can be avoided by use of existing benchmarks. Sub-critical configurations can be tested more readily and at lower cost than critical configurations, although the bias in the results is notably increased. Typically, a critical experiment is used to provide a baseline for subsequent sub-critical experiments to provide assurance in the measured results. Both sub-critical and critical experiments can be used to evaluate the effect of modifying conceptual reactor designs during the technology development and design evolution stage of a program. Hence, selection of a test facility and test configuration that allows for test of an easily modified configuration (vs. a near-final flight design) would be beneficial during the technology development phase of the program.

As noted in section III.B., the only remaining domestic facility capable of testing critical configurations with HEU is the Critical Experiments Facility, located within the DAF at the NTS, which is operated by LANL. The mission of the CEF is to "conduct experiments on critical assemblies with fissile material at or near criticality in order to explore reactivity phenomena and to operate the assemblies in the region from subcritical through delayed critical to beyond prompt critical.” [JNPO 2010a, 2010b]

LANL / NSTec (which manages the CEF) received DOE approval to commence critical operations at CEF in May 2011. Facility operators have executed a material move within the facility and performed a hand stack on the Planet split table for the initial critical test, conducted on June 15, 2011. The critical experiments test devices Planet, Comet, Flat-Top and Godiva IV were previously located at LANL Technical Area-18, but have recently been moved to the DAF. The initial critical operation on Planet repeats a configuration previously tested at LANL (HEU foils and Lucite plates) to validate the facility operation and quantify facility-related uncertainties in the resulting measurements. A grand opening of the facility is planned for late August 2011, and the initial year of operation is reserved for check-out testing and validation of all facility operations.

\section{IV.B.1. Available Test Devices}

Initial evaluation of the available test devices at the CEF has been conducted. Of the four available devices, Planet and Comet have been identified as potentially being applicable to the FSP qualification testing. Both devices are general purpose, vertical assembly machines (vertical split tables) that can be used to investigate criticality characteristics of different geometries and compositions of fissile material. Both machines include a movable platform with the associated drive assemblies and a stationary support structure. Heterogeneous or homogeneous arrangements of fissile materials are possible using different types and quantities of moderating materials. Neither device includes a flexible drawer configuration similar to what was available at the ZPPR test facility. Planet and Comet were omitted from consideration during the JIMO program due to the limitations to the configuration size that could be tested but the smaller size of the FSP concept relative to the JIMO reactor concept allow them to be considered for the current program.

Comet is a general-purpose vertical assembly table (see Fig. 1) that allows for coarse assembly maneuvers (via hydraulic rams), fine assembly (via a ballslide driven by a computer-controlled stepper motor), and gravity-driven disassembly (shutdown; gravity forces the hydraulic ram table to descend) [Loaiza and 
Gehman 2006; JNPO 2010a]. Comet is intended for the assembly of nuclear materials with moderators, reflectors and neutron absorbers into critical configurations. For safety purposes, a portion of the assembly is placed on the fixed (stationary) table and the remainder is assembled on the movable table. Assembly of the two parts is accomplished by remote control from a separate control room. Comet can accept larger experiment loads than Planet and can perform intermediate energy spectrum experiments. Approach to criticality is accomplished via inverse multiplication measurements; neutron multiplication is measured as a function of separation distance between the stationary and movable experiment components. The ANSI/ANS standard, ANSI/ANS-1-2000, Conduct of Critical Experiments, is applicable to CEF in its entirety.
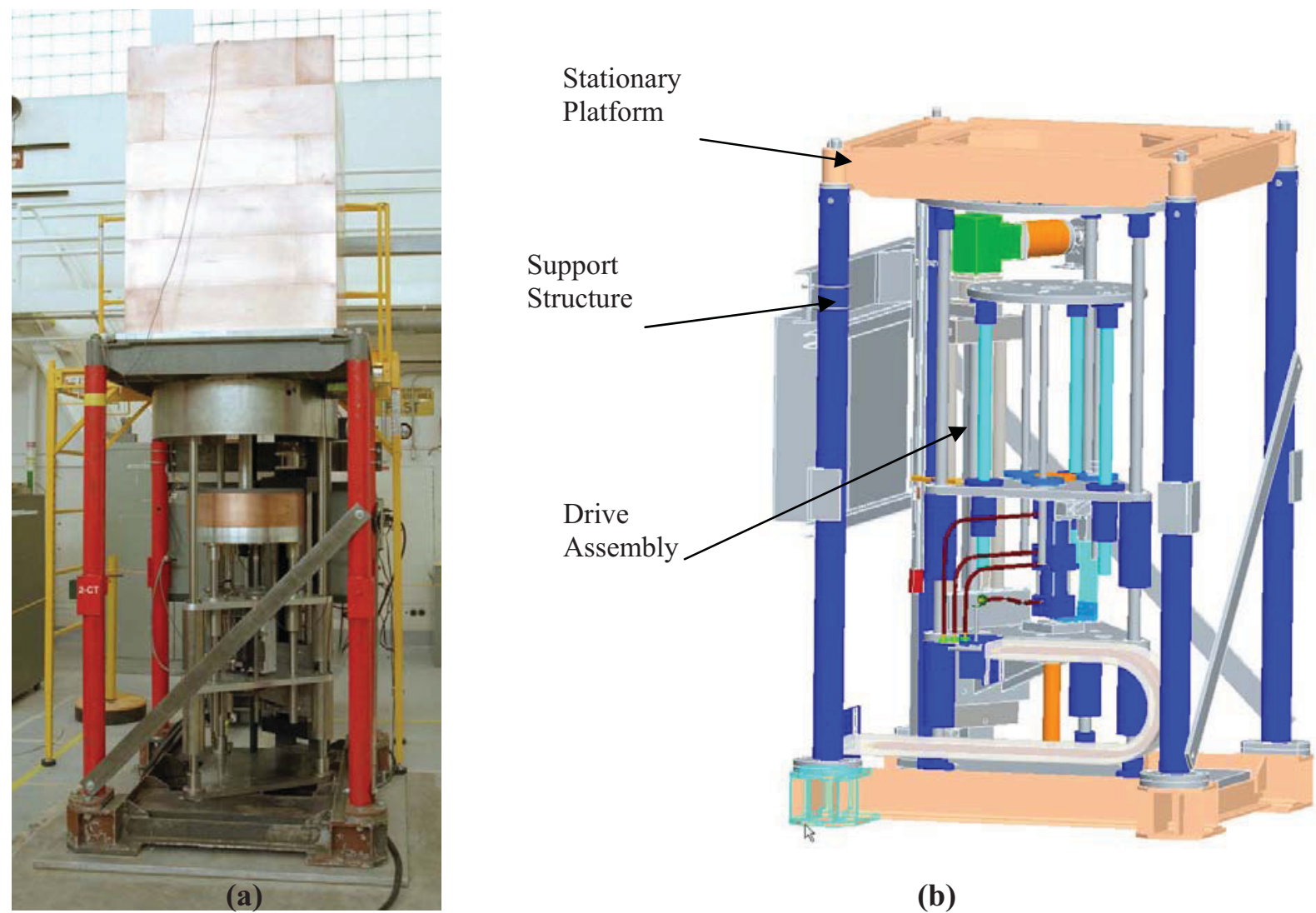

(b)

Figure 1. Comet Vertical Split Table Test Device.

Planet is a vertical-lift critical assembly machine (see Fig. 2) that was originally built as a duplicate for Comet, with a specific focus on providing easy access for students and instructors for hand-stacking operations and demonstrating the effects of various materials, including moderators, reflectors, and poisons [Loaiza and Gehman 2006; JNPO 2010b]. 


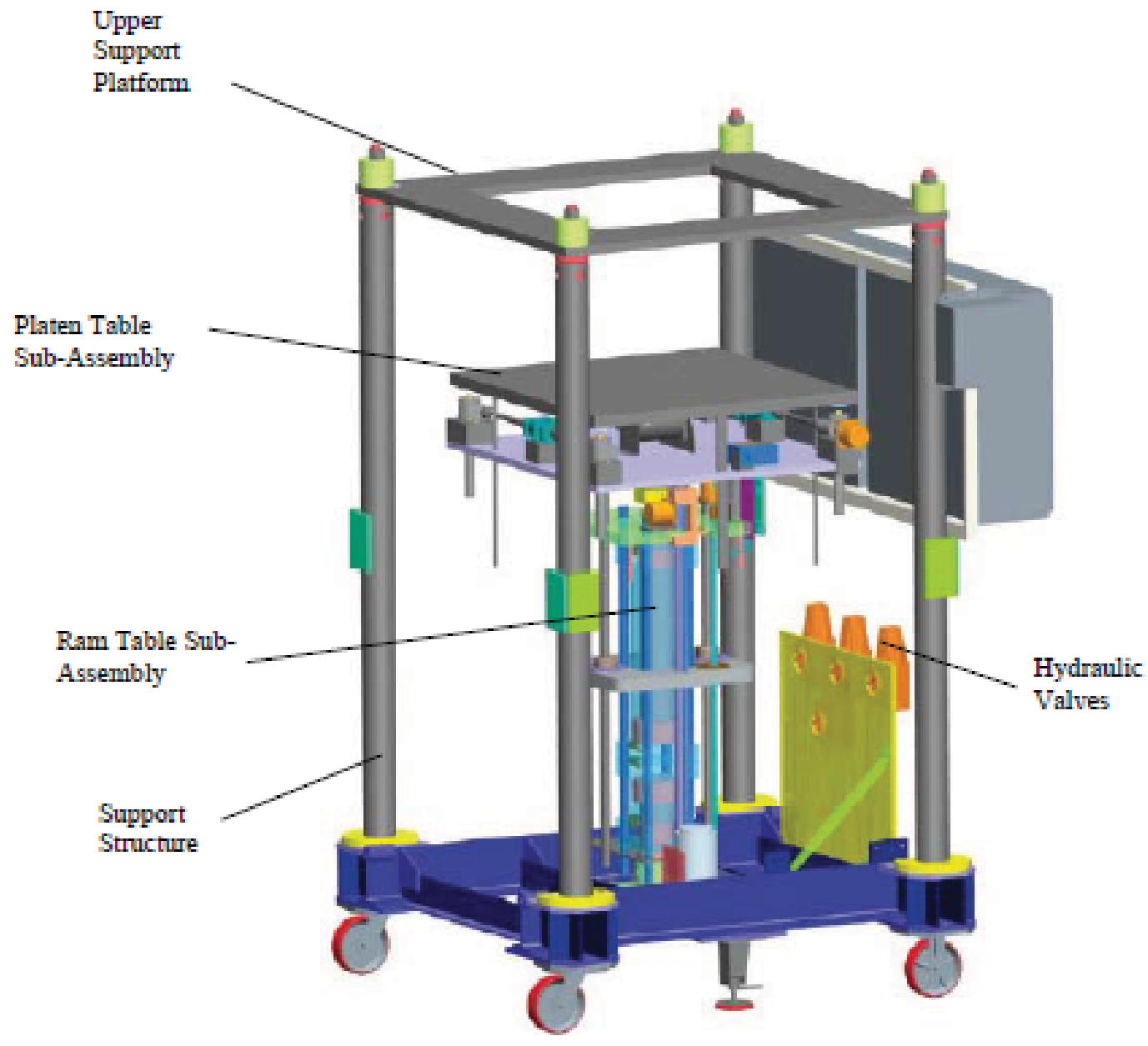

Figure 2. Planet Vertical Split Table Test Device.

\section{IV.B.1. Materials Required for Critical and Sub-Critical Testing}

Numerous structural materials and special nuclear materials (including uranium and plutonium) are currently in storage at the ZPPR Facility at the INL. These materials were previously used in criticality tests performed at the ZPPR facility. The horizontal split table used in the previous tests, such as the ZPPR-16 and -20 series conducted for the SP-100 reactor, has been decommissioned, such that the facility is no longer an option for reactor physics testing. Efforts are currently under way to obtain a master list of materials currently stored at ZPPR.

Many of the special nuclear materials (SNM) stored at ZPPR are slated for dispositioning if they are not identified for use in the relatively near future. It is highly recommended that the FSP program flag any 
existing materials that may be needed for the qualification testing of the FSP design in the very near future, lest they be destroyed. It is currently uncertain how long the materials would then be available before they are destroyed. The ZPPR plates are beginning to oxidize and must be cleaned prior to shipment. Recent analytical data on the HEU plates is limited. INL has performed analysis on samples from major groupings of plates (4 samples / series). If these plates are of interest to the FSP program, it will need to be determined if the historical analysis data and the current analytical sampling provides a sufficient material pedigree for FSP physics testing. If the plate oxidation is problematic to their use at the $\mathrm{CEF}$, the HEU metal may need to be re-canned in a cladding material.

Various non-SNM materials of interest to possible FSP testing have been requested by CEF for shipment from INL. Details on what materials are or may be available at CEF for FSP use will be discussed at the planned August 2011 meeting at CEF. It is anticipated that the material amounts requested by CEF would be more than sufficient for the FSP program; however, details on the material form will be needed for further assessment of their potential applicability.

Estimated material masses from the current FSP conceptual design are summarized in Table 7. Questions may be raised if large amounts of materials, specifically SNM, are asked to be "set aside" for a future test program, but the amounts necessary for an FSP test program are likely to be small enough as to not generate political issues.

As testing needs for the FSP program are defined, a list of applicable SNM types and forms that may be acceptable for critical / subcritical physics testing should be generated, prioritized, and costed. Some material forms may be in existence within the DOE complex, while others may need to be formed from feedstock. Forms could include pin-type $\mathrm{HEU}-\mathrm{O}_{2}, \mathrm{HEU}$ metal, $\mathrm{HEU}-\mathrm{O}_{2}$ powder, $\mathrm{U}_{3} \mathrm{O}_{8}$ powder or solid, and others. It is expected that an acceptable critical mock-up would require $>90 \%$ enrichment in ${ }^{235} \mathrm{U}$, but analysis should be performed to assess the minimum acceptable enrichment for validation and verification activities directed toward minimizing uncertainty in the FSP conceptual design. 
Table 7. Potential material needs for FSP reactor physics testing. Possible material masses needed for critical / subcritical testing would be higher than that included in the conceptual design to allow flexibility in testing several possible design configurations and postulated accident scenarios.

\begin{tabular}{|c|c|}
\hline Material & FSP Mass (kg) \\
\hline \multicolumn{2}{|l|}{ Fuel and Components } \\
\hline HEU metal & $\mathrm{n} / \mathrm{a}$ \\
\hline HEU-O ${ }_{2}$ (pellets) & 85 \\
\hline \multicolumn{2}{|l|}{ Sodium carbonate plates } \\
\hline \multicolumn{2}{|l|}{ (used in conjunction w/HEU metal to simulate $\mathrm{HEU}-\mathrm{O}_{2}$ ) } \\
\hline \multicolumn{2}{|l|}{ Reflector \& Structure } \\
\hline \multicolumn{2}{|l|}{ Beryllium } \\
\hline \multicolumn{2}{|l|}{ (axial reflector, radial reflector meat, drum meat) } \\
\hline Beryllium Oxide & $\mathrm{n} / \mathrm{a}$ \\
\hline Stainless Steel - 316L (clad, vessel) & 44 \\
\hline Stainless Steel -316L (reactor structure, drum clad, radial & \\
\hline \multicolumn{2}{|l|}{ reflector clad, miscellaneous, ) } \\
\hline Inconel 718 & $\mathrm{n} / \mathrm{a}$ \\
\hline Hastelloy X & $\mathrm{n} / \mathrm{a}$ \\
\hline HT-9 & $\mathrm{n} / \mathrm{a}$ \\
\hline \multicolumn{2}{|l|}{ Control } \\
\hline Rhenium & $\mathrm{n} / \mathrm{a}$ \\
\hline Boron Carbide (drum poison) & 5 \\
\hline \multicolumn{2}{|l|}{ Coolant } \\
\hline \multicolumn{2}{|l|}{ NaK simulant } \\
\hline Shielding & Total -2361 \\
\hline Boron Carbide (neutron shield) & 2257 \\
\hline Stainless Steel (shield can, gamma shield) & 105 \\
\hline Lithium hydride & $\mathrm{n} / \mathrm{a}$ \\
\hline Depleted uranium & $\mathrm{n} / \mathrm{a}$ \\
\hline \multicolumn{2}{|l|}{ Postulated Accident Scenarios } \\
\hline Polyethylene & $\mathrm{n} / \mathrm{a}$ \\
\hline Quartz (sand) & $\mathrm{n} / \mathrm{a}$ \\
\hline \multicolumn{2}{|c|}{ (Note: Some materials are not currently included in the FSP conceptual design but could be used in an FSP-type } \\
\hline
\end{tabular}




\section{References}

ANSI/ANS-1-2000, Conduct of Critical Experiments (2000).

J. D. BESS, K. C. BLEDSOE, and B. T. REARDEN, "Evaluation of HEU-Beryllium Benchmark Experiments to Improve Computational Analysis of Space Reactors," Proc. NETS 2011, Albuquerque, NM, February 7-10, 2011.

J. D. BESS and J. B. BRIGGS, "Benchmark Development in Support of Generation-IV Reactor Validation (IRPhEP 2010 Handbook)," Proc. ICAPP'10, San Diego, CA, June 13-17, 2010.

J. B. BRIGGS and L. SCOTT, "The International Criticality Safety Benchmark Evaluation Project,” Nucl. Sci. Eng., 145, 1 (2003).

Y. DANON, R.C. BLOCK, M.J. RAPP, F.J. SAGLIME, G. LEINWEBER, D.P. BARRY, N.J. DRINDAK, and J.G. HOOLE, "Beryllium and Graphite High-Accuracy Total Cross-Section Measurements in the Energy Range from 24 to $900 \mathrm{keV}$," Nuclear Science and Engineering,161, 321-330 (2009).

V. F. DEAN, “The Benchmark Evaluation Process: From Experimental Data to Benchmark Model,” Nucl. Sci. Eng., 145, 20 (2003).

M. E. DUNN, "PUFF-III: A Code for Processing ENDF Uncertainty Data Into Multigroup Covariance Matrices," ORNL/TM-199/234 (NUREG/CR-6650), Oak Ridge National Laboratory (2000).

M.S. EL-GENK and J.-M. TOURNIER, Conceptual design of HP-STMCs space reactor power system for $110 \mathrm{~kW}_{\mathrm{e}}$. In: M.S. El-Genk, Editor, Proceedings of the Space Technology and Applications International Forum (STAIF2004), Ed. by M.S. El-Genk, AIP Conference Proceedings 699, Melville, NY, pp. 658-672 (2004a)

M.S. EL-GENK and J.-M. TOURNIER, SAIRS—Scalable AMTEC Integrated Reactor Space Power System, Prog. Nucl. Energ. 45, pp. 25-69 (2004b).

G. HALE, Los Alamos National Laboratory, Personal Communication, June 9, 2011.

G.A. HARMS and A.D. BARBER, Applicability of Existing Critical Experiments with Beryllium Reflectors to Code Validations for the NASA Fission Surface Power Reactor System, Sandia National Laboratories, Draft Report, January 9, 2009 (2009).

International Handbook of Evaluated Criticality Safety Benchmark Experiments, NEA/NSC/DOC(95)03, OECDNEA, Paris (2010).

International Handbook of Evaluated Reactor Physics Benchmark Experiments, NEA/NSC/DOC(2006)1, OECDNEA, Paris (2011).

A.A. JARRETT, SNAP-2 Summary Report, Atomics International Report No. AI-AEC-13068, July 27, 1973.

Joint Nevada Program Office (JNPO), Comet General Purpose Critical Assembly System Design Description, prepared by J. Anderson, CEF-ENG-SDD-0346 (2010a).

Joint Nevada Program Office (JNPO), Planet General Purpose Critical Assembly System Design Description, prepared by J. Anderson, CEF-ENG-SDD-0347 (2010b). 
J.C. KING and M.S. EL-GENK, "Submersion-Subcritical Safe Space (S4) Reactor," Nuclear Engineering and Design, 236(17), pp. 1759-1777 (2006).

D. LOAIZA and D. GEHMAN, "End of an Era for the Los Alamos Critical Experiments Facility: History of critical assemblies and experiments (1946-2004)," Annals of Nuclear Energy, 33, pp. 1339-1359 (2006).

T.F. MARCILLE, JIMO Reactor Module: Critical Benchmark Experiment Review for Application to JIMO, LA-CP04-0706 (2004a).

T.F. MARCILLE, JIMO Reactor Module: ZPPR-16 and ZPPR-20 Qualification Task, LA-CP-04-0723 (2004b).

J.T. MIHALCZO, “A Small Beryllium-Reflected UO 2 Assembly,” ORNL-TM-655 (1963).

National Aeronautics and Space Administration, Fission Surface Power Team, Fission Surface Power System Initial Concept Definition, NASA/TM-2010-216722 (2010).

Naval Reactors Primary Contractor Team (NRPCT), Project Prometheus Reactor Module: Final Report, SPP67110-0008 (2006).

D.N. OLSEN, et al., "Experiments for the SP-100 Space Reactor in ZPPR-20," INL/EXT-05-00556 \& ANL-ZPR497 (2005).

D.N. OLSEN, et al., "Configurations for SP-100 Experiments in ZPPR-20," INL/EXT-05-00558 \& ANL-ZPR-498 (2005).

E.L. PARADIA, et al., "LCRE Critical Experiments,” PWAC-404 (1964).

J.R. PARRY, J.D. BESS, B.T. REARDEN, and G.A. HARMS, Assessment of Zero Power Critical Experiments and Needs for a Fission Surface Power System, INL/EXT-08-14678 (2008).

C.A. PORTER, S.V. ANDRE, and R.A. DONCALS, SP-100 Critical Experiments Validation Report, SP-RPT-90051 (1990).

D.I. POSTON, Nuclear safety calculations for heatpipe power system reactors. In: M.S. El-Genk, Editor, Proceedings of the Space Technology and Applications International Forum (STAIF-2002), AIP Conference Proceedings 608 Melville, NY (2002), pp. 748-758.

D.I. POSTON, et al., "Reference Reactor Module for the Affordable Fission Surface Power System," in Proceedings of the Space Technologies and Applications International Forum (STAIF-2008), Ed. by M.S. El-Genk, AIP Conference Proceedings 969, Melville, NY (2008).

D.I. POSTON, R. KAPERNICK, D. DIXON, J. WERNER, A.L. QUALLS, and R.F. RADEL,"Reference Reactor Module Design for NASA’s Lunar Fission Surface Power System," Proceedings of Nuclear and Emerging Technologies for Space 2009, Atlanta, GA, paper 208589 (2009).

D.W. STAUB (Ed.), SNAP Programs Summary Report, Atomics International Report No. AI-AEC-13067, July 30, 1973. 
P.H. STELSON and E.C. CAMPBELL, "Cross Section for the 9Be(n,a)6He Reaction, Physical Review, 106(6), pp. 1252 - 1255 (1957).

V.C. TRUSCELLO and L.L. RUTGER, “The SP_100 Power Systems," Proceedings of the $9^{\text {th }}$ Symposium on Space Nuclear Power Systems, Albuquerque, NM, Jan. 12-16, 1992, Pt. 1, New York: AIP Press, American Institute of Physics, p. 1-23 (1992).

K.D. WEAVER, Fission Surface Power (FSP): Cold Critical and Hot Critical Nuclear Testing, INL/INT-07-12996 (2007). 